\title{
Hong Kong's Public Enforcement Model of Investor Protection
}

\author{
David C. DONALD* \\ Faculty of Law, Chinese University of Hong Kong \\ Paul W.H. CHEUK** \\ Faculty of Law, Chinese University of Hong Kong
}

\begin{abstract}
The market of a successful financial centre must be efficient, orderly, and fair, which requires that investor protection rules be enforced effectively. While a substantial literature exists promoting privately driven enforcement of investor protection rules, there is a growing consensus that enforcement action by public bodies is likely to be more important for most markets than privately initiated litigation. Hong Kong exemplifies this point. In Hong Kong, public authorities carry almost the entire burden of enforcing corporate and securities laws. Yet Hong Kong functions at a high level of quality globally despite operating a market in which most companies are foreign-incorporated-often originating from jurisdictions with reputations for governance that are middling at best-and trading takes place in multiple currencies. To revisit the debate on the determinants of effective corporate and securities law enforcement, this paper evaluates the enforcement of investor protection laws in Hong Kong. The paper first examines the institutional context, presenting key corporate and securities regulation and explaining avenues for private and public actions. It looks at the powers and competencies of the relevant supervisory authorities, including the stock exchange, which has a quasi-public role in regulating the market. Then, using publicly available data supplemented through interviews with agency staff, the paper presents Hong Kong's enforcement "inputs" (funding and staffing) and "outputs" (actions and sanctions) for the main public enforcers. We find evidence that the Hong Kong public enforcement model effectively disciplines even its dangerous environment of foreign companies, controlling shareholders, and complex, international groups, and might be able better to do so exactly because of a focus on public, rather than private, enforcement.
\end{abstract}

Keywords: investor protection, corporate law, securities law, derivative actions, disqualification of directors, unfair prejudice

\footnotetext{
* Professor, Faculty of Law, Chinese University of Hong Kong. I would like to thank the Hong Kong Research Grants Council for the generous funding of this work under the Theme-Based Research Project, "Enhancing Hong Kong's Future as a Leading International Financial Centre" (T31-717/12-R). We would like to thank the Hong Kong Companies Registry and the Securities and Futures Commission, as well as Mr Laurence Li, for discussions about and information on enforcement in Hong Kong. We also thank John Armour, Bernie Black, Jim Cox, Robin Huang, and Howell Jackson for their comments on an earlier draft of this paper. All errors remain our own. Correspondence to David Donald, Faculty of Law, Lee Shau Kee Building, The Chinese University of Hong Kong, Shatin, Hong Kong. E-mail address:dcdonald@cuhk.edu.hk.

** Researcher, Faculty of Law, Chinese University of Hong Kong, for the Theme-Based Research Project, "Enhancing Hong Kong's Future as a Leading International Financial Centre" (T31-717/12-R).
} 


\section{INTRODUCTION: THE ENFORCEMENT DEBATE AND ITS IMPORTANCE FOR DEVELOPMENT POLICY}

Between 2000 and the beginning of the global financial crisis, much of the corporate and securities law scholarship_-both by legal and economics scholars-debated the relative merits of various legal systems for protecting the interests of investors in publicly listed companies. The context for this debate was the understanding that investor protection contributes to (or is at least strongly correlated with) the development of a capital marketsbased financial system. ${ }^{1}$ During the debate, it became apparent that high-quality law and regulations were not enough to guarantee fair and balanced regulation. ${ }^{2}$ Good laws and rules could be enacted or issued by a jurisdiction, regulatory body, or securities exchange to signal quality oversight to the world, yet not be effectively enforced. Enforcement could also be selective or biased in such a way that the announced ends of the regulatory framework are not supported or are even thwarted. In such a case, regulation for fairness and efficiency would be signalled but not realized. Such a regulatory Potemkin village would give casual observers unfounded reassurance of regulatory soundness while luring investors into a potentially high-risk environment. For this reason, the debate turned to include enforcement of investor protection laws as an important criterion for assessment, and criteria going deeper than the letter of the law were sought for purposes of this assessment. ${ }^{3}$

One aspect of this analysis was the comparative law question of whether judicial action by damaged shareholders (private enforcement) or a combination of administrative and judicial action by public authorities (public enforcement) was the most effective route to protect investors. An early and enormously influential verdict by a team of economists was that private remedies are more effective than public. ${ }^{4}$ This argument was accepted and advocated by the World Bank, ${ }^{5}$ among others. ${ }^{6}$ Responses by legal scholars Jackson, Roe, and Coffee argued the opposite. ${ }^{7}$ The question is particularly important for developing countries like China, where the legal system is still a work in progress, and for international financial centres (IFCs) like Hong Kong, which continuously review their law and institutions in a competitive bid to attract the favour of the world financial community's investments and deals to their jurisdiction. ${ }^{8}$ IFCs are expected to meet international opinion as to best practices in financial regulation, and are rated accordingly. As Hong Kong is a part of China and has a relatively young financial regulatory system compared to other leading IFCs like London and New York, the debate on the quality of enforcement model is of particular importance for Hong Kong's continued development. In addition, Hong Kong could aspire

1. The issue is discussed at length in Dam (2006).

2. This point was effectively raised in the context of law and development by Berkowitz et al. (2003), pp. 164-5 (referring to Russia, the authors observe that "The most common complaint is that while the transplanted law is now on the books, the enforcement of these new laws is quite ineffective").

3. An important paper in this new inclusion of enforcement was Coffee (2007), discussed below in Section 2.

4. See e.g. La Porta et al. (2006) (these authors are collectively referred to in the following as "LLSV").

5. Worldbank.org (2006) ("In banking and securities markets, characteristics related to private monitoring and enforcement drive development more than public enforcement measures"), cited in Jackson \& Roe (2009).

6. For example, the IMF; see Frankel et al. (2003) ("Financial sector institutions are particularly relevant for the IMF... given the importance of such institutions as protection of shareholders rights, and the possibility that they are deeply rooted in history and culture").

7. See Jackson \& Roe, supra note 5; and Coffee, supra note 3. These two papers are discussed in detail below.

8. This regulatory competitive aspect of IFCs is explained in Donald (2014), pp. 1-3. 
to be not only a student of what has previously been done in the West, but also to innovatively develop a better framework for good governance and financial regulation. Thus, a detailed analysis of enforcement in an IFC like Hong Kong, which has been rated as a "global leader" for a number of years by one rating 9 and highly competitive by others, ${ }^{10}$ yet faces particularly strong challenges in the policing of its market, presents a useful case for understanding the parameters of effective enforcement for the broader debate.

Hong Kong also offers interesting patterns for the broader debate on law and development with respect to whether good law leads to financial market development or the reverse. History shows that the causal relationship between the quality of law and the existence of a financial centre in Hong Kong goes two ways. First, there is evidence to suggest that Hong Kong was deliberately chosen to be built up as a financial centre in order to serve China's economic development needs. ${ }^{11}$ Hong Kong would have been favoured over Shanghai for a number of reasons: it had a working legal system originating from the respected English tradition and a solid scandal-free judiciary ${ }^{12}$; it also had a currency that was fully and freely convertible

9. According to the Global Financial Centres Index (GFCI), Hong Kong has for most years since the index's inception ranked globally at third place (after New York and London), in terms of its competitive position as a global financial centre. See Longfinance.net (2017).

10. For example, the Xinhua-Dow Jones International Financial Centers Development Index ranked Hong Kong at 4th place in 2016, after New York, London, and Tokyo. The World Bank ease of doing business ranking also placed Hong Kong at 4th.

11. See e.g. Meng (2011) ("In April 1992, when, during his Beijing trip, then Chairman of the SEHK, Charles Lee, lobbied Premier Zhu again on Chinese companies listing in Hong Kong, Premier Zhu immediately promised to select 10 companies as experimental listing candidates").

12. The Rule of Law Index 2016 ranked Hong Kong globally at 16th, the third highest in Asia after Singapore and Japan, and above US at 18th; see Worldjusticeproject.org (2016). Score factors include constraints on government powers, absence of corruption, fundamental rights, regulatory enforcement, civil justice, criminal justice, open government, and order and security.

In recent years, there has been a series of significant events that have surrounded the autonomy and judiciary independence of Hong Kong with controversy. On 10 June 2014, the Chinese Central Government's State Council promulgated the "White Paper on the Practice of the 'One Country, Two Systems' Policy in the Hong Kong Special Administrative Region." The White Paper emphasized the overriding unity of the state, which although normal in all sovereign nations, had not been discussed in any detail in the context of "one country, two systems." This White Paper, together with a 31 August 2014 decision to execute a planned extension of democracy on a limited level only (without popular nomination of candidates), was the nominal cause for protests in the form of unprecedented street occupation that lasted for about three months. These brought Hong Kong into the international media as the primary launching point for protests against China - a significant change from its role as China's star financial centre. See a discussion of the White Paper by Sevastopulo (2014). For a discussion of the street protests, see Jacques (2014). Perhaps the greatest shock to Hong Kong's sanctity as a jurisdiction with Western rule of law came when a number of partners in a business publishing books depicting Chinese Communist Party members engaged in unethical and often bawdy conduct disappeared, one from Thailand and another from Hong Kong. It is widely understood that these extractions were performed by Chinese security forces. See Leavenworth (2016).

The latest events of this type followed the election of a number of persons to the Hong Kong Legislative Council who advocated the secession of Hong Kong from China. When the council introduced a loyalty oath to stymie the secessionist movement, a number of legislators tested the oath, one by using vulgar language that indirectly called for a repeated Japanese domination of China ("the people's re-f*cking of Sheena"). While the Hong Kong court deliberated a challenge brought to the validity of the oath, the Chinese National People's Congress Standing Committee used its interpretive power under the Hong Kong Basic Law to pre-empt the court's decision and bar two dissident legislatorselect from taking office. See New York Times Editorial (2016).

While these events are often seen in the international press as signs of China's malevolent presence in Hong Kongrather than in the context of the populist movements that swept through the world in 2016-it may be that they have not seriously affected the overall perception of Hong Kong rule of law. As mentioned above, the World Justice Project Rule of Law Index has been favourable. Hong Kong not only held its place throughout these turbulent years, but its ranking has consistently raised, from 24th in 2014, 17th in 2015, to 16th in 2016 (the only subcategory score that has gone down is the score on "open government"). Also, China's reliance on Hong Kong as its international financial centre does not seem to have diminished, as can be seen in the approval of increasing market linkages: first for the Hong Kong-Shanghai market link in 2014, and then the Hong Kong-Shenzhen link in 2016. 
(unlike the RMB of mainland China). Moreover, Hong Kong's semi-autonomous status allowed its legal system to maintain the characteristics trusted by foreign financial institutions without disrupting the Chinese central government's control over other regions in its territory. Thus, although Hong Kong law could not in any way be considered exceptional when the accord was signed in 1984 to transfer the region back to China, ${ }^{13}$ over the last 30 years, the legal system has been consistently built up to its current state, which easily meets international best practices, as this paper and other studies have shown. ${ }^{14}$

Here we focus on one salient aspect of the Hong Kong legal system: the enforcement of corporate and securities law in Hong Kong is achieved almost solely through public authorities. In jurisdictions where private enforcement is effective, it enjoys structural buttressing through the rules of the legal profession and procedural forms of action: in particular, contingent fees ${ }^{15}$ and class actions. ${ }^{16}$ Neither of these is currently possible in Hong Kong. ${ }^{17}$ Given the economic risk of entering into derivative litigation (in which any damages payment goes to the company) or securities litigation (where an individual investor's losses might not be substantial), few Hong Kong investors initiate a derivative or securities fraud actions. ${ }^{18}$ Hong Kong courts' use of the English rule for litigation costs can also contribute to this hesitation to sue. ${ }^{19}$ As a result, beyond the few corporate derivative and unfair prejudice actions filed annually, as discussed in Section 3.3, all corporate and securities law enforcement in Hong Kong is undertaken by public bodies. ${ }^{20}$ As such, if we were to evaluate effective enforcement focusing primarily on the output of private actions, we would find Hong Kong investor protection to be greatly lacking. However, Hong Kong law functions at a highly competitive level globally while regulating a market largely comprising foreign companies incorporated in jurisdictions whose governance records are questionable. $^{21}$ This feat stands in stark contrast to a conclusion that Hong Kong law lacks quality because of too public an enforcement model.

The determinants of effective corporate and securities law enforcement as drawn from the current state of the debate on investor protection referred to above also indicate that public enforcement is likely to be more important than private enforcement for the success of

13. At that time, the corporate law dated to 1932 and only two rudimentary securities law statutes had been adopted. This is discussed at length in Donald, supra note 8, pp. 111-23.

14. The development of Hong Kong regulatory regime will be discussed in Sections 3.1 and 3.2. Also see Arner (2016).

15. A derivative action is filed by a shareholder on behalf of a company, and the company receives any payout of damages from the action, which has a direct impact on a shareholder-plaintiff's incentives. For a theoretical and empirically based discussion of the impact of attorney's fees structures on litigation, see Eisenberg \& Miller (2012); Eisenberg \& Miller (2006); Eisenberg \& Miller (2004).

16. Where contingent fees are used, the class action allows the total potential payout to be multiplied considerably. The effect of class action lawsuits in the US on firms and investors has been extensively researched by James Cox and Randall Thomas; see Bai et al. (2010); Cox et al. (2008); Cox \& Thomas (2006); Cox \& Thomas (2002).

17. Hong Kong has studied the adoption of a form of class action in which similarly situated investors could bundle their claims in a single action. In 2012, a Law Reform Commission recommended that a class action form be introduced in Hong Kong, initially for consumer rights litigation, but no further action had since been taken as at the end of 2016.

18. Case data of private actions will be presented in Section 4.2.

19. The "cost-shifting" English rule provides that the losing party would pay for the other side's attorney fees, justified on ground of fairness and also as a means to discourage frivolous litigation. On the nature and impact of the English rule for attorney fees, see Eisenberg \& Miller (2012), supra note 15; Vermeulen \& Zetzsche (2010).

20. As will be explained in Section 3, three of the four "public bodies" discussed are not fully public. Two are entities run at a profit independently of the government budget and one is a listed stock corporation. However, they are entrusted with important public functions.

21. For example, Panama, the British Virgin Islands, the Cayman Islands, and Bermuda. 
a financial system. ${ }^{22}$ These determinants will be discussed in Section 2 of this paper. Section 2 takes from this debate that an assessment should focus on three elements: (1) laws and rules regulating the market and its participants, including both potential penalties and abstract regulatory powers, (2) the "inputs" (funding and staffing) into supervisory bodies, and (3) the "outputs" (actions and sanctions) of those bodies, but argues that ultimate "outputs" should be given the most weight. Section 3 examines the Hong Kong institutional context. This includes a summary of key corporate and securities law rules, avenues for private actions, the powers and competencies of its supervisory authorities (including the stock exchange), and the "inputs" into those bodies. Section 4 presents data on "outputs" of institutional enforcement (public bodies plus the stock exchange), the types and numbers of enforcement actions undertaken, and their success rate. To allow readers to understand the Hong Kong enforcement context completely, both public and private actions are explained, and data are offered for both types of actions. This section expressly considers the various levels of sanctions imposed, with particular focus on the "disqualification" from holding a director position, and how its impact differs from that of civil damages. Section 5 presents our conclusions.

\section{DETERMINANTS OF EFFECTIVE ENFORCEMENT}

As will be explained in Section 3, Hong Kong is both relatively new as a financial centre and has an economy in which financial activity is crucial. Its stock market capitalization greatly exceeds its gross domestic product (GDP) and the largest segment of its labour force engages in financial and related professional services. ${ }^{23}$ It can even be argued that Hong Kong's level of political autonomy and the state of its human rights protection are at least indirectly dependent on its continued importance as an international financial centre for China. ${ }^{24}$ It is therefore no exaggeration to say that effectively dealing with the protection of investors is of crucial importance to the success of Hong Kong.

Simple but popular methods used to evaluate the quality of corporate and financial regulation range from collecting anecdotes from persons engaged in the financial industry ${ }^{25}$ to cataloguing abstract prohibitions and regulatory powers as culled from reading the corporate and securities laws or a survey done on the same, or interviewing experts familiar

22. We draw especially from Coffee, supra note 3; and Jackson \& Roe, supra note 5. See below in Section 2.

23. Hong Kong Census and Statistics Department (2015), pp. 31-2.

24. Hong Kong's political autonomy and human rights safeguards are provided for in the Hong Kong Basic Law, the region's mini Constitution, which was written in the context of the former colony's return to China. Arts 16-23 provide for the city's special political status by allowing legislative power, independent judiciary power, and prohibiting any department of the Central People's Government to intervene, whereas Arts $25-41$ provide for various rights, including freedom of speech, freedom of conscience, and access to justice. The Basic Law of Hong Kong also focuses on preserving Hong Kong's existing system of capitalism in place before the handover in 1997. Hence, Arts 105-135 set out in detail the requirements to maintain all its pre-existing features, such as independent taxation system, independent currency, and free movement of capital, as well as a requirement to "provide an appropriate economic and legal environment for the maintenance of the status of Hong Kong as an international financial center." These guarantees obviously have been useful in allowing Hong Kong to create a financial enclave comparable to London or New York under the ultimate control of China, so that market capitalization could increase nearly 60-fold from about HK\$420 billion in 1986 to over HK\$24 trillion in 2016, as discussed in Section 3.1 .

25. This is a central aspect of the ratings undertaken by the Z/Yen Group in its GFCI, 20 of which have been published semi-annually since 2007. 
with the law. ${ }^{26}$ Both of these approaches lack requisite concrete objectivity. Objectivity is a problem because the opinions of market participants interviewed may be both random and self-serving. Questionnaires sent to attorneys may be incorrectly formulated due to a preliminary lack of knowledge, and the answers to the same may be cautiously bland, safely adhering to the letter of the law or regulation. Hence while the work of LLSV and others concludes that private law enforcement is more important than public enforcement, ${ }^{27}$ more recent studies found problems with their analysis. ${ }^{28}$ It is also worth noting because "common-law" jurisdictions are often lumped together that, despite the similarity of law and regulation in the UK and US, very significant differences in approach exist. ${ }^{29}$

Concrete understanding thus is necessary because corporate and securities laws of course operate in the context of other laws and rules, and are applied within an institutional framework. The behaviour of persons charged with implementing a regulatory framework is subjected to various restrictions, incentives, and disincentives-legal, institutional, and economic. The behaviour of the persons targeted by enforcement also arises within a rich institutional context, including the presence or absence of insurance to pay for liability ${ }^{30}$ and the potential impact on reputation and damage to it. ${ }^{31}$ Thus, the complexity of the legal dimension is matched or exceeded by the multiplicity of relationships within the institutional and social dimensions of both enforcement officials and the economic actors they regulate. ${ }^{32}$ As Coates has recently observed, "the main units of variation and change in finance are not things, or even individuals, but groups of people_-groups with not only economic but also social and political relations." ${ }^{, 3}$ The problem of effective enforcement thus presents at least three interrelated fields of relationships: that of the rules, that of the regulators, and that of the regulated. Analysis encompassing legal, institutional, economic, and social contexts is not only highly complex and deeply interesting, ${ }^{34}$ but is one on which we appear to be making progress. $^{35}$

Since the early 2000s, a significant body of objective and concrete work has been produced on corporate and securities law enforcement, combining legal expertise of detail, a deep

26. See e.g. La Porta et al. (1997), p. 1149, using an International Country Risk Guide to evaluate the quality of law, or La Porta et al., supra note 4, pp. 15-6, using questionnaires sent to attorneys. Echeverri-Gent \& Bloom (2010), in their panel analysis of 85 countries on politics of financial market development, found only weak support for a legal origin explanation.

27. See La Porta et al., supra note 4 .

28. For example, some argued that the LLSV studies might not have singled out the variables contributing to market outcomes, and did not consider the fact that jurisdictions with good private legal frameworks may also be those with better public regulators; see Carvajal \& Elliott (2009). Jackson \& Zhang (2017) present an extensive review on studies subsequent to LLSV's efforts, and the findings from more recent studies suggest causality from public enforcement to positive market outcomes.

29. See e.g. Armour et al. (2009). In a review of empirical evidence, Deakin suggested that this is due to traditions in the UK that give shareholders legal power of control, which their US counterparts often lack; see Deakin (2010), p. 534.

30. O'Sullivan (1997); Griffith (2006).

31. Damages imposed in enforcement cases might be shifted to investors, whereas the corporate insiders or insurers could be in a relatively benefited position. Reforms have been suggested to apply greater managerial liability; see Coffee (2006).

32. A contextual perspective based on the economic actors is explored by Cumming et al. (2015), which reveals that the consequence of public and private enforcement differs according to firm size, with public enforcement facilitating securities issuance of smaller firms, more than that of larger firms.

33. Coates (2014), pp. 89-90.

34. This is, of course, a standard feature of comparative law; see Zweigert \& Kötz (1998, §3); and Katz (2009). Contextual analysis also entails "functional" analysis. See Michaels (2006); and Kraakman et al. (2009).

35. See Milhaupt \& Pistor (2008). See also Siems (2010). 
knowledge of market realities, and rigorous empirical analyses of broad datasets. ${ }^{36}$ In a series of important articles, Cox and Thomas explained the relationship between public and private enforcement, ${ }^{37}$ the role of institutional investors - and plaintiffs generally-in securities class actions, ${ }^{38}$ and the correct regulatory framework to optimize the utility of such actions. ${ }^{39}$ This research significantly expanded the set of variables that we understood as necessary to examine in evaluating law in the enforcement context, and provided detailed instruction on the complexity of interrelationships between these variables. In a set of important articles going well beyond an evaluation of the Delaware General Corporation Law and applying a fine balance of legal expertise, market understanding, and empirical rigour, Armour, Black, and Cheffins examined the evolving position of Delaware as a venue for litigation in its competition for corporate charters. They use empirical evidence to raise the novel issue that Delaware's much-praised judiciary may be of little avail in regulatory competition because corporate litigation is migrating elsewhere, and explained the fine balance that must be achieved between pleasing both incorporating directors and the plaintiff's bar. ${ }^{40}$ They also show that the quality and tenor of the Delaware judiciary are not the only or even the main causal factors for this trend, and provide economic historical evidence of developments in the legal profession that have dislocated important corporate actions from their original venue in Wilmington. ${ }^{41}$

Two important articles among this newer scholarship have specifically focused on enforcement in securities markets, and are directly applicable to the project of this paper. In the first, Jackson and Roe empirically examined the assertion that judicial action by private plaintiffs is more closely correlated to financial market growth than is the creation of (even powerful) regulatory bodies. ${ }^{42}$ Their study points out that an abstract cataloguing of regulatory powers cannot alone explain how regulation works, given the rich institutional and motivational environment in which enforcement activity takes place. ${ }^{43}$ As an alternative to an abstract list, they plot ratios between regulatory bodies' budget and national GDP and staffing in relation to national population and the size of a jurisdiction's capital markets, showing that resources expended in public regulation strongly correlate with the success of a financial centre. ${ }^{44}$ Importantly for this paper, Jackson and Roe explain that they have chosen to focus on input factors rather than enforcement outcome for three reasons, one of which is the unavailability of output data. ${ }^{45}$ By examining Hong Kong data in detail, this paper helps to address that lack, at least for one jurisdiction. The second two factors Jackson and Roe provide for using input rather than output are that, first, enforcement volume could be ambiguous in that low volume could indicate either a shirking regulator or a law-abiding market (perhaps cowering in awe of potential regulatory

36. See e.g. Cox \& Thomas (2009). See also discussion of the regulatory trends after 2008 in Ferran et al. (2012).

37. Cox \& Thomas (2003); Cox \& Thomas (2005b).

38. Cox \& Thomas (2002), supra note 16; Cox \& Thomas (2005a).

39. Cox \& Thomas (2006), supra note 16; Cox et al. (2008), supra note 16.

40. Armour et al. (2012a); Armour et al. (2012b).

41. Cheffins et al. (2012).

42. Jackson \& Roe, supra note 5.

43. Ibid., p. 208.

44. Ibid., pp. 237-8.

45. Ibid., p. 211. See also a recent empirical study by Lohse et al. (2014). Using funding data of SEC from the 1940s to 2010, they argue correlation indicating unidirectional causality between the independent variable of increases in SEC budgets and improvement in the compliance behaviour of regulated firms. 
power) and, second, "the mechanisms of enforcement differ across national boundaries," with some relying on "informal discussion" (e.g. the UK), while others need formal actions as deterrent. ${ }^{46}$ In the case of Hong Kong, because companies, their owners, and their directors come from every part of the world, it is difficult to make a judgement about a uniform enforcement culture. However, strong enforcement in Hong Kong can be assumed for our purposes as useful because many economic actors in Hong Kong have been shaped by mainland Chinese history, in which traditional economic law was first condemned in a Marxist sense as a tool of class oppression, then pragmatically understood post 1978 as a hurdle to business that could be adjusted or avoided with the right connections. ${ }^{47}$ Given the limited size of the Hong Kong financial community and the proximity of regulators, the importance of informal discussion cannot be overestimated but, if, behind the friendly consultation, stands strong enforcement, this would tend to concentrate the mind wonderfully. ${ }^{48}$ As such, information about enforcement output is in our opinion highly relevant to the quality of corporate and securities law in Hong Kong. ${ }^{49}$

A second article on the determinants of enforcement that is directly applicable to our paper is a theoretical study by Coffee, which sets out to build on work by Jackson and uses available empirical data on enforcement inputs and outputs for both private and public actions. ${ }^{50}$ The paper analyses the data in the context of incentives for actors, the needs and interests of various constituencies, and the relationship of enforcement to financial services development. His view of the necessary determinants, which we have found instructive and adopted in this paper, can be summarized as follows:

1. the regulatory structure, and the allocation of regulatory powers and discretion among regulators and private actors;

2. the resources invested, in terms of budget and staff, in securities regulation; and

3. the number of actions securities regulators initiate, and the sanctions they impose. ${ }^{51}$

46. Jackson \& Roe, supra note 5, p. 211. Johnston \& Petacchi (2017) conduct a study looking at earnings announcement before and after issuance of over 6,000 SEC comment letters, concluding that such action by SEC increases voluntary disclosure, decreases abnormal returns and trade volume, and has positive informational effects.

47. One of the authors has discussed the history of China in relationship to anti-corruption efforts elsewhere, with further citations to sociological work in the area; Donald (2013). On the issue of cross-border interaction, in its assessment, IMF opined that "the inherent complexity of running enforcement cases in this environment, such as obtaining evidence in a country as large and diverse as the Mainland, and the interaction between two systems of law" to be significant challenges to maintain effective enforcement process; see IMF.org (2014), p. 99. Despite the challenge to effective enforcement, we think that these cross-border and cross-jurisdiction circumstances signify even higher importance for public enforcement in Hong Kong, over private remedies.

48. As per eighteenth-century English writer, Samuel Johnson. This perception of enforcement is important and regulatory agencies could benefit from knowledge of public perception. Some regulators, such as the UK FCA, have begun using surveys to assess the perception of market participants on the effectiveness of enforcement programmes. Survey data would help to capture the effect of these informal channels. See Armour et al., supra note 29, p. 31.

49. During 2013, Hong Kong completed the detailed assessment required of by the IMF Financial Sector Assessment Program (FSAP). The assessment was conducted based on the 38 IOSCO Principles and Objectives of Securities Regulation approved in 2010. Principle 12 ("The regulatory system should ensure an effective and credible use of inspection, investigation, surveillance and enforcement powers and implementation of an effective compliance program") is of relevance to enforcement output, and enforcement output figures up to 2013 were assessed and reported in its detailed assessment report; IMF.org, supra note 47. FSAP did not give Hong Kong the highest rating in this respect, with one reason being there was a "public disagreement between SFC and the former DPP in connection with the handling of criminal cases" (p. 98). This will be further discussed below in Section 3.4.1.

50. Coffee, supra note 3.

51. Ibid., p. 255. 
A particularly important point Coffee raises is that enforcement measures must be calibrated to create real deterrence affecting potential wrongdoers. On this point, he argues that high civil damages against companies and directors in the US are

both too little ... and too much - too little in that the outside professionals are rarely sued and corporate officers often pay nothing, and too much in that the corporation itself is regularly sued and settles at the shareholders' expense. ${ }^{52}$

Coffee finds that this consideration supports the efficacy of enforcement actions by the US Securities and Exchange Commission (SEC). ${ }^{53}$ This has relevance for the nature of the deterrent often employed in Hong Kong, which is disqualification from holding a director position. $^{54}$

The following Sections 3 and 4 present the enforcement of corporate and securities laws in Hong Kong based on the law seen in context and actual output. Section 3 examines the institutional framework for enforcement, including laws and regulatory bodies, and Section 4 presents data on enforcement output, with a focus on actions to disqualify directors.

\section{THE HONG KONG MARKET AND THE INSTITUTIONAL FRAMEWORK FOR ENFORCEMENT}

\subsection{The Hong Kong Market}

The Hong Kong capital market is greatly a product of the rise of the Chinese economy over the three decades from 1980, and its regulatory framework was largely created as a channel to finance this growth during the same period. The market capitalization of the Stock Exchange of Hong Kong (SEHK) grew by about 17-fold between 1976 and 1991, from about HK\$56.7 billion to HK\$949.2 billion $^{55}$ - an absolute increase of about HK\$892 billion. Then, in the two decades from 1992, the year before the first mainland Chinese enterprise was listed, ${ }^{56}$ its market capitalization multiplied again by another 17-fold, to exceed HK\$24 trillion by the end of $2016^{57}$-an absolute increase of about HK\$23.8 trillion. Between the announcement of Hong Kong's return to China and 2016, SEHK market capitalization increased about 60 -fold. "M8 "Mainland enterprises" constitute more than $62 \%$ of 2015 SEHK

52. Cheffins et al., supra note 41, p. 305 . On the other hand, one study shows how compensation bought by public enforcement can help fill a void where private law may leave investors with no effective remedies; Velikonja (2015). This is also exemplified in recent Hong Kong enforcement cases such as HKSAR v. Du Jun [2012] HKEC 1280 and HKSAR v. Du Jun [2012] HKCA 39, to be discussed in Section 4.3.2.

53. Coffee, supra note 3, pp. 304-6. Indeed, in the years after Coffee's article, the SEC bought several high-profile insider trading prosecutions, including one in which SAC Capital agreed to pay a record fine of $\$ 1.8$ billion and pleading guilty (Birmingham Retirement and Relief System v. SAC Capital Advisors LP, U.S. District Court, Southern District of New York, No. 13-02459). See Hurtado \& Keller (2016). Study found significant association between deterrence effect among peers of fraudulent firms and SEC enforcement actions, and suggested that repeated and sustained enforcement provide more effective deterrence; see Jennings et al. (2012).

54. Hong Kong's regime for disqualification will be discussed below in Section 4.3.

55. Hong Kong Exchanges and Clearing Limited (2000). Hong Kong Exchanges and Clearing Limited is referred to hereinafter as HKEx.

56. Ibid. The H-Shares of Tsingtao Brewery Co. Ltd began trading on the SEHK on 15 July 1993.

57. HKEx (2017b).

58. The growth is HK\$24.007 trillion, from HK\$419 billion to HK\$24.761 trillion.

59. Ibid., the category "Mainland enterprises" includes (1) companies incorporated in the People's Republic of China and listed on the SEHK ("H share" firms), (2) those incorporated in the PRC, but not part of the H Share programme 
market capitalization. ${ }^{60}$ Thus the Hong Kong capital market is both new and greatly dependent on its ability to serve as a window for international investment in Chinese enterprises. This background has made Hong Kong in recent years a market that remains focused on raising capital (rather than trading existing listings), and its volume of initial public offerings (IPOs) has retained a prominent place globally. ${ }^{61}$

Hong Kong is unquestionably a financial centre, and traded assets dwarf productive activity, such that the market capitalization of SEHK in 2016 was more than ten times Hong Kong's GDP of HK\$2.48 trillion. ${ }^{62}$ Companies listed on the SEHK are rarely incorporated in Hong Kong, and can be divided into five groups, with $48.9 \%$ incorporated in the Cayman Islands, $26.3 \%$ incorporated in Bermuda, $12.2 \%$ incorporated under the law of mainland China, only $10.7 \%$ incorporated in Hong Kong itself, and the remaining $1.87 \%$ incorporated elsewhere. ${ }^{63}$ Regardless of where these companies are incorporated, most have their major business operations in China, and thus bring with them into Hong Kong the regulatory risks of mainland China. Moreover, the leading constituent stocks of the Hang Seng Index (HSI), except for the financial companies, all have controlling shareholders ${ }^{64}$ which can reduce agency problems between managers and shareholders, but brings its own challenges of controlling shareholder abuse.

The supervision of securities trading in the Hong Kong market is facilitated by the fact that the market structure for equity trading in Hong Kong is mainly concentrated on one exchange, but complicated by the large number of broker-dealers and the significant discrepancy in size and sophistication between local intermediaries and the multinational broker-dealer banks. ${ }^{65}$ As at March 2016, the SEHK had 537 exchange participants (about the same number as the New York Stock Exchange (NYSE)), ${ }^{66}$ but only about $12 \%$ of these were also admitted to trading on the HKFE. ${ }^{67}$ This dual membership can serve as a proxy for large, internationally active broker-dealers, providing evidence of participant size on the SEHK. As is evident from Table 1, Hong Kong's market is nearly six times smaller than New York's, the world's largest market, but about five times larger than Singapore's, a fellow IFC in Asia. However, unlike Singapore and even more unlike New York, the majority of companies listed in Hong Kong are foreign-incorporated, and thus this large IFC with a small domestic economy must regulate companies incorporated under foreign laws, the shape of which it cannot control.

Hong Kong's regulatory infrastructure, which will be discussed in the following sections, ${ }^{68}$ is nearly as new as its post-1984 skyrocketing increase in market volume.

\footnotetext{
(F'note continued)

("non-H-share Mainland private enterprise"), and (3) those incorporated in Hong Kong or elsewhere, controlled by residents of the PRC, and listed on the SEHK ("red chip" firms).

60. Ibid., p. 23.

61. See Table 1.

62. Ibid., pp. 1-2; and Hong Kong Census and Statistics Department, Hong Kong Monthly Digest of Statistics 83 (June 2015).

63. HKEx, supra note 57, pp. 28, 601; discussed in Donald, supra note 8, pp. 101-3.

64. Donald, supra note 8, Chapter 2.

65. Discussed in Donald (2012, Chapter 6).

66. World Federation of Exchanges figures for Equity Trading Participants, 2012.

67. SFC (2016), p. 40.

68. See Section 3.4.
} 
Table 1. Figures for 2015 in US\$ million ${ }^{\mathrm{a}}$

\begin{tabular}{lccc}
\hline & Hong Kong & Singapore & New York \\
\hline Market capitalization & $3,184,874.2$ & $639,955.9$ & $17,786,787.4$ \\
IPOs (capital) & $33,942.5$ & 407.2 & $13,033.1$ \\
No. of listed companies & 1,866 & 769 & 2,424 \\
Foreign listings (\% of total) & $6 \%\left(88.6 \%^{\mathrm{b}}\right)$ & $37.2 \%$ & $21 \%$
\end{tabular}

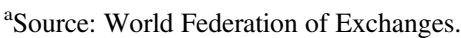

${ }^{b}$ HKEx provides information on only a few companies under the rubric "foreign" because it has created a category of acceptable overseas jurisdictions for companies to cross-list, although those companies are in fact not incorporated under Hong Kong law. These are referred to as "overseas" companies and, if they are counted as "foreign" (which they factually are), then only $11.36 \%$ of companies listed on the SEHK are not foreign-incorporated.

The first secondary market legislation was adopted in $1974^{69}$ and the law reached its current shape with the codification of the Securities and Futures Ordinance (SFO) in $2003 .^{70}$ The governmental market regulator, the Hong Kong Securities and Futures Commission (SFC), was created in $1989 .^{71}$ The stock market was formed in 1986 from a consolidation of four smaller venues ${ }^{72}$ and the parent company that finally brought the stock and futures exchanges together within one collateral management system was created in $2000 .^{73}$ The first major rewrite of the Hong Kong corporation law in about 140 years came into effect in $2014 .^{74}$

\subsection{Key Rules for Investor Protection}

A reading of Hong Kong's rules designed to protect investors shows them to compare well to those of other major financial centres, in both corporate and securities law. This section will briefly outline the kinds of rules that the enforcement actions discussed in Section 4 carry out and offer supplementary information as necessary to understand the specific shape of the Hong Kong legal framework. The provisions of law and regulation presented are those in corporate law designed to address the three relationships often characterized as agency problems - between shareholders and management, between majority and minority shareholders, and between shareholders and creditors-for which company law has developed countervailing strategies. ${ }^{75}$ In Hong Kong, these are found in the Companies Ordinance and the common law on companies, as expressed in the decisions of Hong Kong, UK, and Commonwealth courts. ${ }^{76}$ The provisions of securities law discussed are those designed to

69. These were the Securities Ordinance CAP 333 and the Protection of Investors Ordinance CAP 335, both of which came into effect in March 1974.

70. The Securities and Futures Ordinance, L.N. 12 of 2003, 1 April 2003, hereinafter "SFO."

71. This was done by means of the Securities and Futures Commission Ordinance, L.N. 162 of 1989, 1 May 1989.

72. The Stock Exchanges Unification Ordinance, CAP 361, 1 February 1981. Pursuant to s. 27, commencement date of the ordinance was 2 April 1986.

73. This was the Hong Kong Securities Clearing Company Ltd (HKEx).

74. The Hong Kong Companies Ordinance CAP 622, hereinafter "CO."

75. Kraakman et al. (2009).

76. Since 1997, Hong Kong is no longer bound by the decisions of the Privy Council, but takes its decisions, as well as those of the UK Supreme Court (former House of Lords) and Commonwealth courts, as persuasive authority. The boundaries of Hong Kong common law are presented in the HK Court of Final Appeal decision, Solicitor v. Law Society of Hong Kong [2008] 2 HKLRD 576. 
govern what are seen as the central concerns of securities regulation ${ }^{77}$ : the governance and disclosure of corporate issuers and fair and orderly secondary market trading. These provisions are found in the SFO.

The Companies Ordinance contains a two-stage duty of care, consisting first of an objective functional standard and second of a subjective add-on component. It requires that a director exercise the "care, skill and diligence" of a director carrying out the "functions" of a director in relation to the company, and also requires that the director exhibit "the general knowledge, skill and experience that the director has."78 The provision expressly states that this duty is owed to the company (not to the shareholders, another constituency, or to the company for the benefit of the shareholders). ${ }^{79}$ Hong Kong also applies the common-law director's fiduciary duty, requiring "a director to act in the best interests of the company," so that a director "may not put himself or herself in a position where his or her interest and duty conflict." 80

These duties may be enforced judicially through actions prosecuted by company members or by the SFC (if the company is listed). The ordinance also contains statutory rules requiring that material conflicts of interest be disclosed to the board ${ }^{81}$ and prohibiting most loans to directors absent specific approval from shareholders. ${ }^{82}$ As explained above, because the vast majority of listed companies are not incorporated in Hong Kong, these duties will not apply directly to most listed companies. However, an outreach provision in the Companies Ordinance provides that both derivative and unfair prejudice actions may be filed against foreign companies listed in Hong Kong (referred to as non-Hong Kong companies). ${ }^{83}$ Also, the SEHK Listing Rules contain both a duty of care and a fiduciary duty, and the SFC has the authority to file actions against all listed companies for breach of duty or other misfeasance. ${ }^{84}$ In this way, all local and non-local companies listed in Hong Kong are bound by the Hong Kong directors' duties. ${ }^{85}$

Since 1911, the Companies Ordinance has contained provisions imposing civil liability for material untrue statements in securities prospectuses. ${ }^{86}$ To these, criminal liability provisions were added in 1972, and both are currently found in the Companies (Winding Up and Miscellaneous Provisions) Ordinance (CWUMPO), ${ }^{87}$ but should eventually be transferred to the SFO. No change in the provisions on prospectuses has been discussed, other than a possible clarification that underwriting sponsors will also be liable for the prospectus. Despite the provision's 100-year history, however, there is no record of any private action

77. Langevoort (2009), p. 1027.

78. CO s. $465(2)$.

79. CO s. 465(3). By contrast, see UK law, Companies Act 2006, s. 172.

80. Poon Ka Man Jason v. Cheng Wai Tao [2016] HKEC 759, para. 72-4, Court of Final Appeal.

81. CO s. 536.

82. CO ss. 491-515.

83. CO s. 722, in connection with CO ss. 2 and 774 as well as the common-law definition of "place of business" as set out in Kam Leung Sui Kwan v. Kam Kwan Lai [2015] 18 HKCFAR 501.

84. SFO s. 214.

85. SEHK Listing Rules, Rule 3.08.

86. See Companies Ordinance, No. 58 of 1911, s. 86.

87. See Companies Winding Up and Miscellaneous Provisions Ordinance CAP 32, ss. 40 and 40A, hereinafter CWUMPO. Civil liability runs to all directors and persons authorizing issue of the prospectus. A "due diligence" defence for statements made after reasonable inspection is available for all parties. 
ever being filed alleging the publication of untrue or misleading statements in a securities prospectus. Since 2014, the Companies Ordinance also contains a criminal sanction for the intentional or reckless omission of material statements from an auditor's report, ${ }^{88}$ but this provision remains untested.

Like the primary market, the secondary market is governed by a standard assortment of rules specifying prohibited acts. The SFO prohibits false or misleading disclosures, ${ }^{89}$ insider dealing, ${ }^{90}$ and a number of forms of market manipulation. ${ }^{91}$ Hong Kong expressly prohibits combinations of trades likely to create unsupported price pressure and is thus well placed to combat algorithms designed to engage in trade-based market manipulation by both moving price and harvesting the differences of such movement. ${ }^{92}$ The SFC uses the Nasdaq SMARTS surveillance system to monitor for this and other patterns that might evidence market abuse. The SFO also imposes a duty on listed companies to disclose inside information that "has come to its knowledge" 93 as rapidly and fairly as practicable unless the information is a trade secret or concerns ongoing negotiations and the confidentiality of the information is preserved. ${ }^{94}$

The SEHK Exchange Rules are ordinary in that they require regular (albeit not quarterly) disclosure, ${ }^{95}$ shareholder voting on board composition and major transactions, ${ }^{96}$ and insert both non-executive independent directors and committees (audit and remuneration) dominated by the latter into the board. ${ }^{97}$ In contrast to rules on US exchanges, the SEHK expressly requires that all issued shares of a listed company have equal voting rights ${ }^{98}$ and, standing by this strict position in 2013, lost Hong Kong Alibaba, one of the largest listings in history, to New York. ${ }^{99}$ Another peculiar - and, for Hong Kong, necessary—set of rules are the far-reaching provisions on connected party transactions that require not only disclosure, but abstention from voting for connected parties and an annual review of approved arrangements. ${ }^{100}$ The concept of "connected person" reaches out to include not only economically connected parties, controlled companies, family members, and companies of the latter, but can also include extended family members like grandparents, grandchildren, and nephews, as well as companies owned by them. ${ }^{101}$

\footnotetext{
88. CO s. 408.

89. SFO s. 277 (Disclosure of false or misleading information inducing transactions).

90. SFO s. 270.

91. SFO ss. 274 (False trading), 275 (Price rigging), 278.

92. SFO s. 278.

93. SFO s. $307 \mathrm{~B}(1)$.

94. SFO s. 307D(2). Similar exceptions apply to the receipt of liquidity from the government Exchange Fund and cases where the SFC has waived the requirement because disclosure would violate local or foreign law. SFO s. 307E.

95. SEHK Listing Rules, Chapter 13.

96. SEHK Listing Rules, Chapters 13, 14.

97. The minimum required number of independent non-executive directors in three (Listing Rules, Rule 3.10(1)), which must constitute at least one-third of the board of a listed company (Rule 3.10A). There must also be an audit committee (Rule 3.21) and a remuneration committee (Rule 3.25) comprised solely of non-executive directors (NEDs).

98. SEHK Listing Rules, Rule 8.11.

99. Bullock (2014).

100. SEHK Listing Rules, Rule 14A.03.

101. Ibid., Rule 14A.21.
} 


\subsection{Available Private Actions}

\subsubsection{Derivative Action}

Hong Kong law has both the common-law shareholder derivative action first discussed in the 1843 case of Foss v. Harbottle $e^{102}$ and a statutory derivative action that was introduced into the Companies Ordinance in 2004. ${ }^{103}$ The statutory route exists independently of the common-law action and may be filed against directors for "misconduct," which includes fraud, negligence, a breach of the duty of care, a breach of the fiduciary duty (duty of loyalty), and any failure to comply with a rule of law. ${ }^{104}$ Under the statutory scheme, leave from court must be obtained before a derivative action can go forward, and the statutory hurdle is less burdensome than the common-law principles expressed in Foss and its progeny. The CO contains a four-part test for new proceedings brought by shareholder:

1. the company must not have brought the same proceedings already;

2. the shareholder must have given the company at least 14 days' notice of the proceedings;

3. the action must appear, on the face of the application, to be in the company's interest; and

4. the proceedings must present a serious question to be tried. ${ }^{105}$

Hong Kong courts have found that the plaintiff's burden to show the action is "on the face of the application in the interest of the company," "is not a high one."106 They have held that a court "should be slow to find against the Plaintiff unless his prospects are so slim that he cannot be said to have any expectation of success." ${ }^{107}$ Nevertheless, despite this judicial welcome to such actions, very few have been filed, as will be shown in Section 4.

\subsubsection{Unfair Prejudice Action}

While derivative actions are designed to prevent or punish the illegal behaviour of directors ("misconduct"), an unfair prejudice action is meant to stop legal behaviour of management that is legal but unfairly prejudicial (referred to in the case-law for some reason as "mismanagement"). ${ }^{108}$ The Companies Ordinance contains express provision that a member may seek relief from the court if "the company's affairs are being or have been conducted in a manner unfairly prejudicial to the interests of "one or more member'."109 This is a direct, rather than a derivative action, and it provides relief against the oppressive behaviour of majority shareholders. It is applied when the controlling party has behaved unfairly, which

102. Foss v. Harbottle (1843) 67 ER 189.

103. Introduced by the Companies (Amendment) Ordinance 2004.

104. CO s. 731

105. The version of legislation applied in all the case analyzed here is found in Chapter 32 , s. 168BC(3). The current location of the statutory derivative action prohibitions is in CO ss. 731-8. CO 2012 renders the Latin "prima facie" in English as "on the face of the application."

106. Lucky Money Ltd \& Others [2006] HKEC 1379, paras 40, 41.

107. Li Chung Shing Tong (Holdings) Ltd [2011] HKEC 1192, para. 33.

108. See Re Chime Corp Ltd [2004] 7 HKCFAR 546, 571, citing Hoffmann L.J. in Re Saul D Harrison \& Sons Plc [1995] 1 BCLC 14.

109. CO s. 724(1). 
the courts understand as breaching "equitable constraints" on behaviour. ${ }^{110}$ Such constraints have traditionally been seen to exist primarily in small companies that could be called "quasi-partnerships" but the Hong Kong courts have held that, even in the case of a listed company, assumed compliance with the Listing Rules also presents an equitable constraint, so that shareholder conduct causing the breach of such rules can be unfairly prejudicial. ${ }^{111}$ As a result, the existence of Listing Rules provisions also provide a basis for an action against unfairly prejudicial conduct of members.

\subsubsection{Professional and Procedural Hurdles to Private Actions}

In Hong Kong, the legal profession may not be compensated on a scheme of contingent fees and the rules of procedure do not provide for a class action. Thus, unlike in the US, the fee structure does not give lawyers incentive to carry the risk of an action. As a result, if the damage award will go to the company rather than to the plaintiff (derivative action) or the possible award for fraud or unfair prejudice will not be large, plaintiffs have little incentive to initiate an action. Hong Kong is considering adoption of class action rules, but no decision or date for decision has been made known. ${ }^{12}$ With a loser-pays-costs structure and the lack of class actions, plaintiffs undertaking either derivative or unfair prejudice actions are few. In the case of a listed company, however, the SFC can undertake both types of actions. ${ }^{113}$

\subsection{Supervisory Agencies Authorized to File Actions}

\subsubsection{The Securities and Futures Commission}

The Hong Kong SFC is less than 30 years old and was created in response to the "Black Monday" market crash of October 1987, which halved the Heng Seng Index and bankrupted the Hong Kong Futures Exchange guarantee system. ${ }^{114}$ At that time, the exchanges were largely unregulated except for the need to consult with an informally staffed Commissioner. ${ }^{115}$ Furthermore, in 1988, the chairman of the SEHK, Ronald Li Fook Shiu, was convicted of violating the Prevention of Bribery Ordinance by accepting allotments of shares in return for favourable decisions on listing applications. ${ }^{116}$ The government then appointed a committee of experts whose chief recommendation was to create an independent supervisory authority. ${ }^{117}$ The SFC was established as a statutory body outside of the civil service and given jurisdiction over the Hong Kong securities exchanges by force of the Securities and Futures Commission Ordinance of 1989. ${ }^{118}$ Rather than being “independent,"

110. See O'Neill v. Phillips [1999] 1 WLR 1092.

111. Luck Continent Ltd v. Cheng Chee Tock Theodore [2013] HKEC 1209, para. 83. This was affirmed by the Court of Final Appeal in Final Appeal No. 4 of 2014 (Civil).

112. See Law Reform Commission of Hong Kong (2012). Subsequently to the report, a Working Group was formed by the Hong Kong Department of Justice and, as at the end of 2016, the Working Group has held 16 meetings to study proposals; see Department of Justice (2017).

113. See SFO s. 214.

114. Fell (1992), pp. 196-8.

115. See ibid. on the appointment, duties, and resources of the Hong Kong Securities Commissioner prior to the creation of the SFC.

116. Ibid., pp. 204-6, 214; Attorney General v. Li Fook Shiu, Ronald [1990] 1 HKC 1.

117. SFC (1988), The Operation and Regulation of the Hong Kong Securities Industry, also called the Davison Report. See Fell, supra note 114, p. 204.

118. This power is now found in SFO s. 5(1)(b)(i), as the SFO absorbed and repealed the earlier ordinance. 
it is more accurate to think of the SFC as balancing between the twin forces of government and market influence. From the government side, the Chief Executive of the Hong Kong Special Administrative Region (HKSAR) appoints the chairperson and other commissioners of the SFC ${ }^{119}$ and the chief executive may also instruct the SFC on how to carry out its duties. ${ }^{120}$ From the market side, an "advisory committee" drawn from the financial community in Hong Kong meets "at least" quarterly with the SFC chairperson and chief executive officer to advise them on matters of policy. ${ }^{121}$ SFC performance and procedures are reviewed annually by an independent "Process Review Panel" operating out of the HKSAR Financial Services Branch and originally created by the chief executive in 2000. ${ }^{122}$ The Panel reviews, inter alia, the licensing and regulatory activity of the SFC

on the adequacy of [its] internal procedures and operational guidelines governing the actions taken and operational decisions made by [it] and its staff in the performance of its regulatory functions, including the receipt and handling of complaints, licensing and inspection of intermediaries, and disciplinary action. ${ }^{123}$

Like other supervisory bodies of this type, the SFC's statutory mandate is "to maintain and promote the fairness, efficiency, competitiveness, transparency and orderliness of the securities and futures industry," educate and protect the investing public, and "reduce systemic risks in the securities and futures industry." 124 Its powers and duties include the licensing of market participants, ${ }^{125}$ as well as the continued policing of their behaviour, ${ }^{126}$ and the creation of rules and guidelines to govern these activities. ${ }^{127}$ The SFC is divided into five divisions, which respectively focus on markets supervision, intermediary licensing, corporate finance, China market integration questions, and enforcement. The enforcement division separates its actions into corporate disclosure and governance, intermediary misconduct and unlicensed behaviour, and market manipulation and insider dealing. ${ }^{128}$

When dealing with its own licensees, the SFC can impose licence-related sanctions without recourse to any court or tribunal. ${ }^{129}$ When acting against market misconduct, the SFC may file a civil action in a special-purpose Market Misconduct Tribunal ${ }^{130}$ or, in the Court of First Instance, particularly for injunctive relief, ${ }^{131}$ file a minor criminal action in a

119. SFO Sch. 2, para. 1; formerly Securities and Futures Commission Ordinance s. 5.

120. SFO s. 11.

121. SFO s. 7.

122. See Process Review Panel for the SFC (2012), para. 1.1.

123. Ibid., para. 1.7.

124. SFO s. 4.

125. This applies to all non-banks that would perform a "regulated activity." See Parts III and V of the SFO. "Regulated activities" under the SFO are: (1) dealing in securities; (2) dealing in futures contracts; (3) leveraged foreign exchange trading; (4) advising on securities; (5) advising on futures contracts; (6) advising on corporate finance; (7) providing automated trading services; (8) securities margin financing; (9) asset management; (10) providing credit rating services. See SFO Sch. 5, Pt 1.

126. See SFO s. 388; CWUMPO s. 168I.

127. See SFO s. 397.

128. SFC (2014a), p. 67 ("Investigations by Nature").

129. SFO s. 5. The decisions of an individual division within the SFC can be appealed to the Commission itself, and then to the Securities and Futures Appeals Tribunal. See SFO s. 216.

130. SFO s. 242.

131. This option, although initially challenged, has been expressly upheld by the Hong Kong Court of Final Appeals in the Tiger Asia Management LCC decision, discussed in Section 4.3.1. 
magistrate's court, ${ }^{132}$ or ask the Department of Justice to file a criminal action in the District Court or the Court of First Instance. ${ }^{133}$

In 2012, differences of opinion arose between the SFC and the Hong Kong Director of Public Prosecutions, who expressed concern about the role of the SFC as both regulator and prosecutor, stating a fear of it "becoming judge of its own cause" and arguing that "it is imperative to keep the prosecutorial responsibility separate from regulatory or investigatory agencies." ${ }^{\prime 34}$ For its part, the SFC responded that the Public Prosecutor's office appeared understaffed in respect to securities fraud cases. ${ }^{135}$ In 2016, the two sides seem to have come to an agreement with the signing of a Memorandum of Understanding. ${ }^{136}$ It states that the two have "mutual interest" in dealing with corporate wrongdoing and formalized the handling of cases under the SFO. The Department of Justice also stated that the "power of the SFC to prosecute in its own name does not derogate from the powers of the Secretary for Justice in respect of the prosecution of criminal offences."137

The SFC is funded by a tariff imposed on trading and has not requested funding from government budget since 1993. At least for the current period, the idea of "inputs" as budgeted expenditure for the SFC is not likely to be as important as enforcement "outputs" because the SFC receives much more money than it can spend and, in 2015, had accumulated reserves up to 4.6 times its projected annual expenditure. ${ }^{138}$ Between 2005 and 2015, the SFC reported annual expenditures more than trebling from HK\$497 million in 2005 to about HK\$1.7 billion in 2015, with an increase in expenditures from 2009 to 2015 of $138 \%$. $^{139}$ Despite tripling its spending over the ten-year period, the SFC still showed a surplus of more than HK\$6.3 billion. The SFC reports that an average of approximately $21 \%$ of its staff was dedicated to its enforcement division for the period 2000-16. ${ }^{140}$ In its 2015 annual report, the SFC notes that " [s]taff costs accounted for about $69 \%$ of our total expenditures. Over the past three years, our staff costs increased $45 \%$ while many regulatory activities increased in both number and complexity." ${ }^{141}$ Details on the type, number, and success rate of judicial actions filed are discussed in Section 4, below.

\subsubsection{The Official Receiver}

The Official Receiver (OR) of the HKSAR dates back to 1931 and was modelled on its British equivalent. The current OR is organized under and receives its powers from the

132. SFO s. 388.

133. Under an arrangement reached in 2007 , the SFC refers "all potential market misconduct prosecutions to the Prosecutions Division to assess whether the case should be criminally prosecuted and, if so, whether the case should be prosecuted on indictment by the DOJ in the higher courts or summarily by the SFC in the Magistrates' Courts." See SFC (2013b).

134. Hong Kong Department of Justice (2013).

135. SFC, supra note 133 .

136. This is also in line with recommendation in the IMF financial sector assessment report on Hong Kong issued in 2014. IMF.org, supra note 47, p. 7.

137. Department of Justice \& Securities and Futures Commission (2016).

138. Legislative Council Panel on Financial Affairs (2015), p. 7.

139. Budget information on the SFC is available both from the Commission's annual reports and from the Hong Kong Legislative Council Panel of Financial Affairs, Securities and Futures Commission Budget for the Financial Year (Years 2004-2005 to 2013-14).

140. Calculated from figures in 2000 to 2016 budgets, Legislative Council Panel on Financial Affairs, Securities and Futures Commission Budget for the Financial Year (2000-2017).

141. SFC, Annual Report 2014-15, 80 (2015). 
Hong Kong Bankruptcy Ordinance. ${ }^{142}$ Its mandate is to provide for the orderly management of insolvency proceedings over both individuals and companies where no other provision for a liquidator has been made. ${ }^{143}$ For purposes of this paper, its most important function is to prosecute persons, including corporate directors, ${ }^{144}$ for violations of law in proximity of bankruptcy. ${ }^{145}$ Actions filed by the OR are heard in the Court of First Instance. ${ }^{146}$

Of the four entities discussed in this paper, the OR alone is listed on the general budget of the HKSAR. Over the ten-year period between 2007 and 2016, the OR had average planned annual budgets beginning at approximately $\mathrm{HK} \$ 147$ million and increasing to around HK $\$ 190$ million in 2016-17, with about two-thirds of that going to staffing. ${ }^{147}$ In 2015 , the OR's total staff numbered 242. ${ }^{148}$ The OR has reported that the prosecution office of its enforcement division is staffed by at least seven solicitors, two of whom are designated as "Senior Solicitors," actual number of employees assigned to this office is not fully disclosed. Details on the type, number, and success rate of judicial actions filed are discussed in Section 4, below.

\subsubsection{The Registrar of Companies}

Like the OR, the Hong Kong Registrar of Companies was created with functions and duties tracking its British equivalent. In addition to registering the establishment of companies and providing a preliminary screening of company names, ${ }^{150}$ the Registrar issues guidelines on important questions of company law ${ }^{151}$ and receives a large array of filings and disclosure statements from existing companies. These include "annual returns" 152 that contain information similar in detail to that filed in other jurisdictions only by listed companies, ${ }^{153}$ "statements of capital,"154 "return of allotments,"155 and notices setting out any other changes in a company's capital structure, ${ }^{156}$ such as any repurchase or redemption of shares. ${ }^{157}$ The Companies Registry also records the debt positions of companies through keeping the returns of allotment of debentures ${ }^{158}$ and the register of "charges," 159 as well as

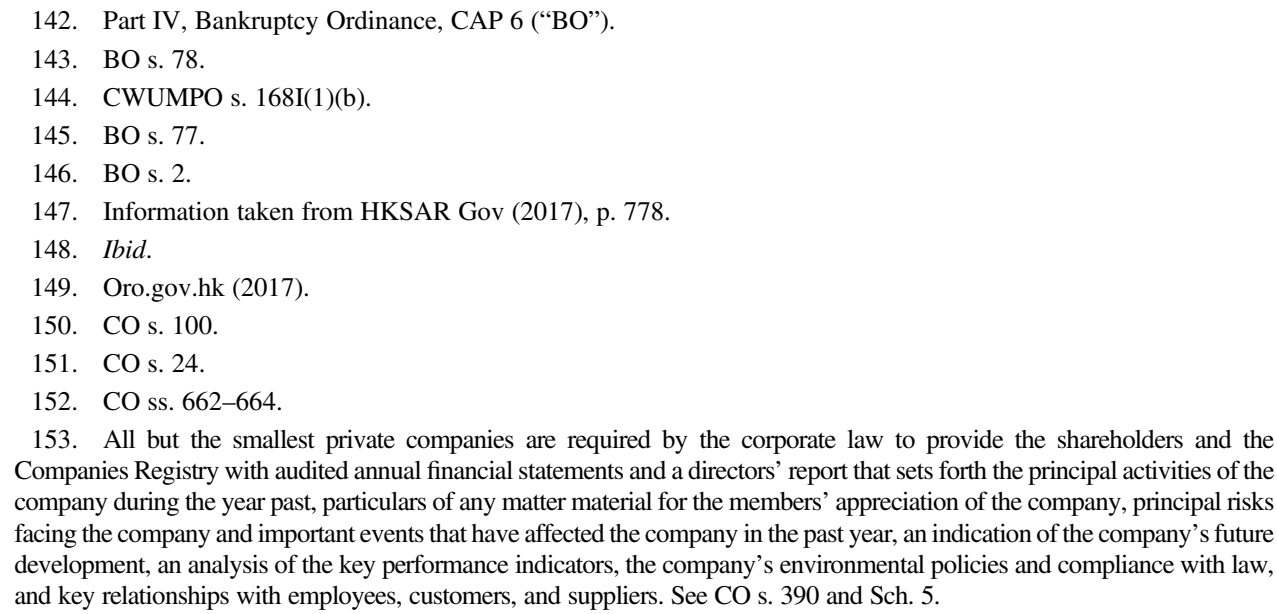

153. All but the smallest private companies are required by the corporate law to provide the shareholders and the Companies Registry with audited annual financial statements and a directors' report that sets forth the principal activities of the company during the year past, particulars of any matter material for the members' appreciation of the company, principal risks facing the company and important events that have affected the company in the past year, an indication of the company's future development, an analysis of the key performance indicators, the company's environmental policies and compliance with law, and key relationships with employees, customers, and suppliers. See CO s. 390 and Sch. 5.

154. CO s. 201

155. CO s. 142 .

156. CO s. 171

157. CO s. 270

158. CO s. 316

159. CO s. 338. 
notices by creditors who enforce such charges. ${ }^{160}$ The Companies Registry enforces these various filing obligations with powers of deregistration and fines, as well as by filing judicial actions for the disqualification of directors. We discuss details on the type, number, and success rate of judicial actions in Section 4, below.

Unlike the OR, the Companies Registry is independent of government funding and operates under commercial principles as a self-financing "trading fund." "161 It does so very successfully such that, rather than receiving funds from public budget, it pays the government a handsome dividend. For the ten-year period from 2007 to 2016, the Companies Registry operated in substantial surplus, booking an annual average post-tax profit of $\mathrm{HK}$ \$204 million and paying the Hong Kong government average dividend of HK\$197 million per year. ${ }^{162}$ The registry's staff has increased gradually from 333 in 2007 to 386 in 2016, with an annual average staff for the whole period of $358 .{ }^{163}$ Approximately $14 \%$ of staff is engaged in enforcement. ${ }^{164}$

\subsubsection{Hong Kong Exchanges and Clearing Limited (HKEX)}

The SEHK is the primary regulator of listings and public offerings of securities in Hong Kong. ${ }^{165}$ The SFO gives recognized exchanges like the SEHK (currently the only stock exchange in the HKSAR) the power to adopt binding rules ${ }^{166}$ and allows the SFC to delegate part of its regulatory functions to such a company. ${ }^{167}$ Both the SEHK and its parent company, the HKEx, are tied to the government. The SFO gives the Financial Secretary the right to appoint up to eight members to SEHK's board of directors, ${ }^{168}$ the HKEx' articles of association subject appointment of its chairperson to the approval of the HKSAR chief executive, ${ }^{169}$ and the SFC may veto any proposed appointment to the post of chief executive or chief operating officer of the HKEx. ${ }^{170}$ As such, although the HKEx is a private corporation in which the government has only a $5.88 \%$ holding, ${ }^{171}$ its activities can be thought of as quasi-public in nature. Moreover, the SFC has legally transferred to the SEHK its power under the $\mathrm{CO}$ to examine and authorize prospectuses for the sale of securities ${ }^{172}$ and the SFC has adopted rules placing authority for approving listing applications primarily in the hands of the SEHK. ${ }^{173}$ The result is that the SEHK, unlike other stock exchanges

\footnotetext{
160. CO s. 348.

161. CO s. 26 and Trading Funds Ordinance CAP 430.

162. Companies Registry Annual Reports for the years 2004-16.

163. Ibid.

164. Information provided by the Companies Registry upon request in correspondence.

165. The arrangement described in the subsection is now subject to a joint consultation document proposed by the SFC and the HKEx. This document would introduce somewhat more SFC authority into the process, but would not significantly change the allocation of power as it now stands. See SFC \& HKEx, Joint Consultation Paper on Proposed Enhancements to the Exchange's Decision-Making and Governance Structure for Listing Regulation (June 2016).

166. SFO s. 23.

167. SFO s. 25 .

168. SFO s. 77(1), (5).

169. HKEx Articles of Association, Art. 111(2).

170. Ibid., Art. 111(3)(b).

171. See HKEx minority controllers, at www.hkex.com.hk, About HKEx > Investor Relations > Minority Controllers.

172. Securities and Futures (Transfer of Functions-Stock Exchange Company) Order, CAP 571AE, s. 3.

173. Securities and Futures (Stock Market Listing) Rules, CAP 571V.
} 
(e.g. the NYSE or the London Stock Exchange (LSE), whose regulators review listing documents and determine their contents), administers nearly all of the disclosure regulation for listed companies, including the content and approval of securities prospectuses and annual reports.

As discussed in Section 3.2, above, aside from restriction on dual classes of shares and rather extensive rules on connected party transactions, the SEHK Listing Rules are largely the same as those used on other major stock exchanges. They are enforced by the SEHK Listing Division, which may bring a listed company, its substantial shareholders, or its officers or directors before the Listing Committee for a breach of the Listing Rules, ${ }^{174}$ and may impose sanctions ranging from a private reprimand to the suspension or cancellation of the listing. ${ }^{175}$ For the year 2016, the HKEx reported spending HK\$2.06 billion, or 58\% of its operating expenses, on staff. ${ }^{176}$ It does not provide a breakdown on the portion of staff dedicated to enforcement matters. Details on the type, number, and success rate of disciplinary actions commenced are discussed in Section 4, below.

\section{EXAMINING THE DATA ON ENFORCEMENT ACTIONS IN HONG KONG}

\subsection{Data Examined}

The data examined in this Section 4 are taken from publicly available sources and-where actions were publicly initiated and the enforcement authority's staff members were able and willing to provide additional data beyond what had already been published — supplemented by interviews with the relevant supervisory authority staff. For private actions, the judicial decisions used are those reported in two online databases-WestLaw and Lexis-combining the set where one includes a case decision not published in the other. The cases obtained from these commercial services have been checked against the decisions listed by the Hong Kong judiciary on its website as a control against underinclusion by the commercial databases. Actions counted are limited to those in which either a derivative or an unfair prejudice claim is of central importance to the plaintiff's case, and each set of facts is only counted once, regardless of how far the case may be appealed or how many secondary rulings (such as on motion to amend a pleading or on costs) have been published. SFC actions taken under SFO sections 212-214 that include a claim of unfair prejudice or request action against a director for breach of duty to his or her company are not included in this group of private actions, but separately presented as SFO actions.

Information on SFC actions was assembled using the same commercial databases, plus the SFC's annual reports and enforcement news reporter. ${ }^{177}$ These actions are divided into two groups: actions taken against listed companies to counter director misconduct and actions taken against market misconduct, particularly insider dealing and market manipulation. The vast majority of SFC's other actions, which involve the disciplining of persons licensed to

174. SEHK Disciplinary Procedures, s. 2.4.

175. SEHK Listing Rules, Rule 2A.09.

176. HKEx (2017a), p. 48.

177. The SFC Enforcement News reporter is available at www.sfc.hk, News \& Announcements > Enforcement News. 


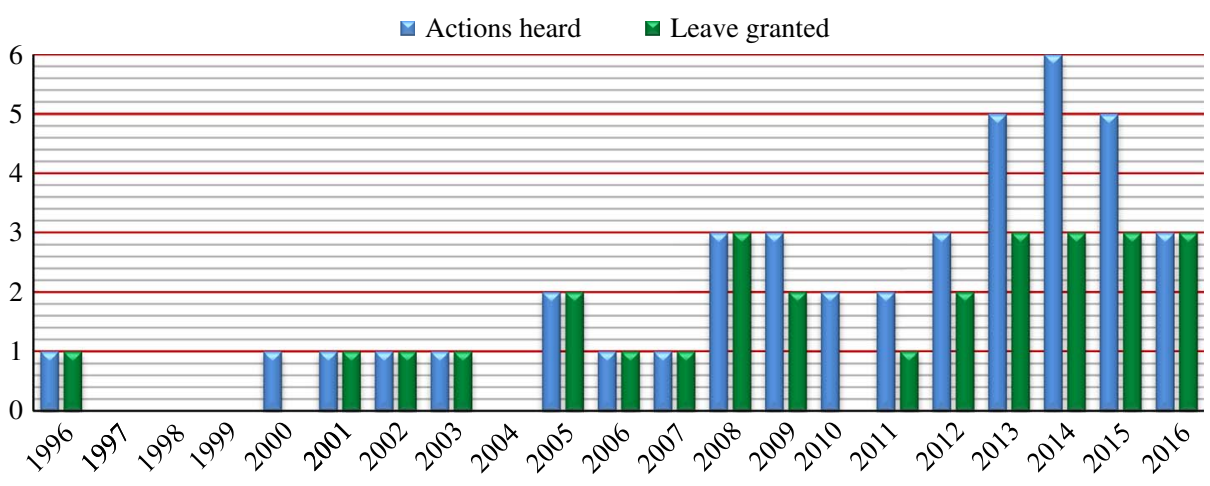

Figure 1. Statutory derivative actions: reported and leave granted

perform brokerage, investment, and advisory services, are not discussed in this paper. ${ }^{178}$ The data regarding Companies Registry actions were similarly assembled on the basis of the registry's annual reports and reported enforcement activity, plus correspondence with registry staff. ${ }^{179}$ As will be seen from the data, the registry files thousands of summons annually and does not provide a case-by-case breakdown of the individual grounds for each action. Thus our discussion of the actions taken will be general, based on correspondence with Companies Registry staff. The data for OR actions to disqualify company directors were assembled from the OR's periodic publicly disclosures on its website. ${ }^{180}$ The OR primarily acts to ensure the orderly winding-up of insolvent debtors in Hong Kong, and the fact that it will take over the records and control of an insolvent company likely has a deterrent effect on the behaviour of corporate directors. However, the information examined here is restricted solely to judicial actions taken either to disqualify directors or to hold them liable for civil damages to the company.

\subsection{Private Actions}

\subsubsection{Derivative Actions}

As Figure 1 makes clear, although the introduction of the statutory derivative action in 2004 strongly correlates with a $440 \%$ increase in the number of actions filed and a near doubling of the absolute number of actions that annually survived dismissal, the total number of actions is still very small. In the period from 2005 to 2016, a total of 36 derivative actions were heard, of which 24 , or about $66 \%$, were successful. The figures indicate a possible trend towards an increase in the filing of derivative actions, but even the historical high of six actions during the year 2014 means that plaintiffs tended to file less than one action for every 225,000 corporations operating in Hong Kong. ${ }^{181}$

178. One of the author has presented and examined this data in Donald, supra note 65, Chapter 5.

179. Companies Registry enforcement data are available at www.cr.gov.hk, Statistics > Prosecution, and Compliance $>$ Highlights of Prosecution Cases.

180. This OR data on enforcement are available at www.oro.gov.hk, Statistics > Statistics on Prosecution and Disqualification.

181. At the close of 2016, there were 1,341,223 locally incorporated companies limited by shares (corporations) and 10,078 companies incorporated abroad, but with a place of business in Hong Kong and thus subject to its jurisdiction for, inter alia, derivative actions. 
Aside from the numerical discrepancy between active companies and actions, a look at the facts of the derivative actions filed shows that the abuse complained of in such actions is as much that of a controlling shareholder as a director. The derivative action is often understood to be an "anti-director" tool with which weak and dispersed shareholders of a Berle and Means corporation can seek justice against professional managers. However, Hong Kong companies are characterized by controlling shareholders. ${ }^{182}$ When controlling shareholders also directly dominate the board, tensions can arise between minority shareholders and controlling shareholders connected to the latter's service on the board, and this can form the basis of a derivative action. If we examine the facts of Hong Kong derivative actions for which leave was granted between 2005 and 2016, we see that, in 19 of the 24 successful actions, the defendants were not only directors of the company, but also substantial shareholders or persons acting in concert with them. ${ }^{183}$ The root of the problem in most of these

182. See the analysis in Donald, supra note 65, Chapter 2.

183. In Yau Wing [2016] HKEC 294, "the Company is $99.9 \%$ owned by Henry Fok Estates Limited. The directors of the Company are three of Mr Fok's children by his first marriage: Ben, Ian and Tim,” ibid., at para. 4. In Primalsk (HK) Ltd [2016] 2 HKLRD 31, "the applicant is a member of the Company holding 25\% of its shareholding. Ramchand [the defendant] is a member of the Company holding the remaining 75\%," ibid., at para. 2. In Chu Kong v. Up Profit Ltd [2016] HKEC 2775, "the Company is wholly owned by Sun Harvest Holdings Limited, a BVI company. Sun Harvest is in turn owned by Mr Chu and a Mr Lau equally," ibid., at para. 2. In Yu Yuchuan v. China Sanshui Investment Co. Ltd [2015] HKEC 437, "the Applicants are minority shareholders of Shanshui Investment, holding 17.44\% of its issued shares ... Mr. Zhang Sr is the registered holder of $81.74 \%$ of Shanshui Investment's issued shares," ibid., at paras 10-11. Re Loong San Investment Co. Ltd [2014] 2 HKLRD 1116 presents a battle among four heirs, none of them holding less than $25 \%$ of any of the companies involved in the dispute; the defendant is the brother who took over management when the father passed away. In Lee Chi Yuen Arctic v. Yuanzhi International Trading Co. Ltd [2013] HKEC 1096, "the applicant and [the defendant] had each become equal shareholders and the only directors of the company," ibid., at para. 8. In David Chien v. Francis Cheung [2013] HKEC 896, the "1st defendant ... [was] the Chairman of the Board of directors and the single largest shareholder of the Company, holding about $40.59 \%$ of its shares," ibid., at para. 4. In Hang Heung Cake Shop Co. Ltd [2013] HKEC 163, "the issued share capital of the HHCS was held as to 75\% by the Cheng family ... and as to the remaining $25 \%$ by the Tsoi family," ibid., at paras 7-8. In New-Asia Optical Co. Ltd [2011] HKEC 1150, the company had "three shareholders. In addition to the Applicant, Lam Chi-cheung was, prior to his death on 26 December 2010, the registered owner of 58 per cent of the Company's share capital," ibid., at para. 2. In AR Evans Capital Partners Ltd v. Gen2 Partners Inc. [2012] HKEC 875, “The Company ... at all material times had three shareholders-Novel Alternative Investment Ltd ('Novel'), Mr Barry Lau Wang-Chi ('Mr Lau') and A R Evans Capital Partners Limited ('AR Evans'), holding respectively 50\%, 10\% and 40\% of its issued shares. Novel is ... owned by Mr Paul Lincoln Heffner ... while AR Evans is ... owned by Mr Raymond Lai. The Company ha[d] three directorsMr Heffner, Mr Lau and Mr Raymond Lai," ibid., at para. 1. In Li Chung Shing Tong (Holdings) Ltd [2011] 5 HKLRD 274 , the primary defendant was "at all material times ... the majority shareholder of the Company [and] a director of the Company for many years until her purported resignation in 19 October 2001, after which she continued to participate in the management of the Company and supervise the operations of the Company. She was reappointed to the board of directors on 30 April 2008," ibid., at para. 6. In FBC Construction Co Ltd v. Big Island Construction (HK) Ltd [2009] HKEC 467, the company was at "all material times ... 99.9999\% owned by 'Big Island Asia' which, in turn, was $99.9 \%$ owned by Ben Lee," the defendant director, ibid., at paras 1-2. In Grand Field Group Holdings Ltd [2009] HKEC 338, after founders of the company left the board and brought in a strategic investor who took a board seat, the defendant board member shareholders allegedly siphoned funds off to their own companies through PRC subsidiaries, ibid., at paras 4-16. In Nice \& Well Ltd [2008] HKEC 2134, the court describes the action as one by "a shareholder and director of the Company" against "its other shareholder and director," ibid., at para. 2. In Waddington Ltd v. Chan Chun Hoo [2008] HKEC 1498, "the 1st defendant ... [was] and at all material times ... Chairman and Executive Director of [the Company] and is alleged to have been a director at the relevant times of each of the companies in the ... group ... Through the 2nd defendant and a family trust he is alleged to hold and, at all material times, to have held an indirect controlling interest in [the Company] and hence in each of its subsidiaries and sub-subsidiaries," ibid., at para. 8. In Myway Ltd [2008] 3 HKLRD 614, the applicant and the opposing respondent were "the only shareholders of the Company, each holding $50 \%$ of its issued shares. They [were] also its only directors," ibid., at para. 3. In Re F\& $S$ Express Ltd [2005] 4 HKLRD 743, which was an action against a Mr Li for siphoning off funds into his own company, the Company allegedly damaged had "three shareholders ... each holding one-third of the shares. The applicant [was] a shareholder. Li Pui Lam [the defendant] [was] another shareholder ... [and] also a director," ibid., at para. 5. In Ng Lee Wah v. Lam Chun Wah \& Another [2005] HKEC 907, the "1st defendant and the plaintiff ... were ... the only two shareholders and directors of the 2nd defendant ('the Company')," ibid., at para. 1. 


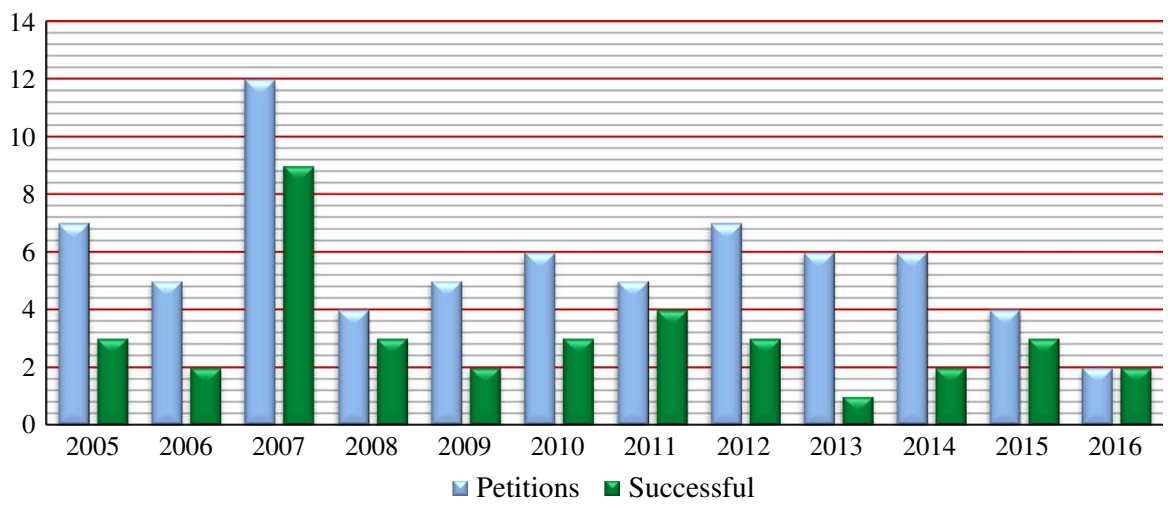

Figure 2. Unfair prejudice actions: filed and successful

actions is therefore the controlling shareholders for, if a dominant shareholder cannot achieve an end otherwise, she may attempt to do so by using access to power or information within the company board. This is not the scenario normally envisaged for derivative action relief, but rather one for which the law would better provide an avenue for direct action against abusive controlling shareholders. In the next section, we present the available data on this remedy: the action against unfairly prejudicial conduct by those in control of the company.

\subsubsection{Unfair Prejudice Actions}

Figure 2 sets out the number of unfair prejudice actions for which decisions were published during the period 2005-16. Few published Hong Kong decisions actually examine in detail the merits of alleged unfair prejudice petitions regarding the management of a company, and instead nearly all were decided on procedural points (such as whether security should be posted, an injunction issued, or petitions be struck) with summary view of facts as presented in the pleadings. ${ }^{184}$ From the published cases referring to unfair prejudice actions, we have made a rather strict selection, including only those decisions where we think the court disposed of the case as an unfair prejudice action (because no other decision on the same facts is published and the determination would appear to have allowed that theory) and excluding actions where it appears from the decision that the court found the unfair prejudice claim to be frivolous or otherwise far-fetched. It would certainly be possible to interpret the constellation of unfair prejudice actions more inclusively, avoiding the kind of judgement calls we have made in focusing on these 69 decisions. ${ }^{185}$

There are on average about six actions annually and a success rate of about $50 \%$. However, as discussed briefly in Section 3, a problem existed in the manner the unfair prejudice action had been restricted to companies in which close or personal relationships existed, allowing the kind of equitable commitments to arise among members primarily as a "quasi-partnership." ${ }^{186}$ In 2013, the Hong Kong Courts of Appeal and Final Appeal took a

184. Also, this selection inevitably omits petitions that might have been bought to the court but where no final judgment was produced, either because it was withdrawn at any stage or settled, for which no collection of numbers was conducted at the moment.

185. This is what was done in Donald, supra note 65, pp. 196-7.

186. See O'Neill v. Phillips [1999] 1 WLR 1092. 
step away from this restrictive reading by affirming that, in the case of a listed company, the tacit understanding that Listing Rules should be complied with also presents an equitable constraint, the breaching of which may constitute unfairly prejudicial conduct. ${ }^{187}$ As a result, listed companies are now eligible for an action against unfairly prejudicial conduct. Even so, at an average of just under six actions per year, there was only about one unfair prejudice action filed for every 200,000 companies operating on a regular basis in Hong Kong. This hardly presents a strong deterrent against management and controlling shareholder misconduct.

\subsection{SFC Actions}

\subsubsection{Actions to Disqualify Directors}

In Hong Kong, all judicial actions taken against false and misleading securities prospectuses or to punish violations of rules against insider dealing or market manipulation have been commenced by a public body. In 2007, the SFC also began filing actions to disqualify corporate directors who breach applicable standards of care or fiduciary duties, or disclose false information to the public, in most cases after they have driven their company into insolvency. ${ }^{188}$ Two associated characteristics of the disqualification action make it attractive: first, it cannot be indemnified against through D\&O insurance, as it attaches directly to the director's person, and, second, although it shares this in personem characteristic with a criminal sanction, the standard of proof used is that for civil cases. ${ }^{189}$ The maximum period of disqualification is 15 years $^{190}$ and the case-law has divided this into three bands of five years each for differing degrees of culpability. ${ }^{191}$

After the SFC first made the strategic decision to brings such actions using SFO section $214,{ }^{192}$ between 2007 and 2014, it obtained 28 disqualification orders in such actions ${ }^{193}$ $40 \%$ more than the 20 successful Hong Kong statutory derivative actions against director misconduct during the same period (Figure 3). Although the initial actions were filed against companies already under investigation, censure, or suspension of listing by the HKEx, the SFC is now beginning to target the misconduct of directors who have not yet driven their companies into insolvency. An example is action taken to disqualify four directors of

187. Luck Continent, supra note 111.

188. The action is provided for in SFO s. 214 for conduct that is "oppressive to its members or any part of" them, involves "defalcation, fraud, misfeasance or other misconduct towards it or its members," results in "members ... not having been given all the information with respect to its business or affairs that they might reasonably expect," or "unfairly prejudicial to its members or any part of its members."

189. Official Receiver v. Chan Kin Hang Danvil [2011] HKEC 1212, para. 30 ("The standard of proof in an application for disqualification is the balance of probabilities").

190. CWUMPO s. 168E(3).

191. See Re Sevenoaks Stationers (Retail) Ltd [1990] BCC 765, cited with approval in Securities and Futures Commission v. Cheung Keng Ching [2011] HKEC 657, para. 36, and Re First China Financial Network [2015] HKEC 2100 ("The top bracket of over 10 years ... for particularly serious cases" including repeat offenders, the "minimum bracket of [below 5 years], applicable to cases where ... they are, relatively, not very serious," and the "middle bracket of 6 to 10 years, applicable to serious cases which do not merit the top bracket").

192. See SFC (2004), p. 23 ("we are taking legal advice on two cases about the prospects of seeking orders under Section 214 of the SFO. The section enables the Court to make a range of orders including disqualifications of directors").

193. The data on SFC enforcement activity used here and in Figure 3 are taken from the SFC's "Enforcement News," published on its website beginning in 1997. SFC "Enforcement News" is available at http://www.sfc.hk/ edistributionWeb/gateway/EN/news-and-announcements/news/enforcement-news (accessed 5 June 2017). 


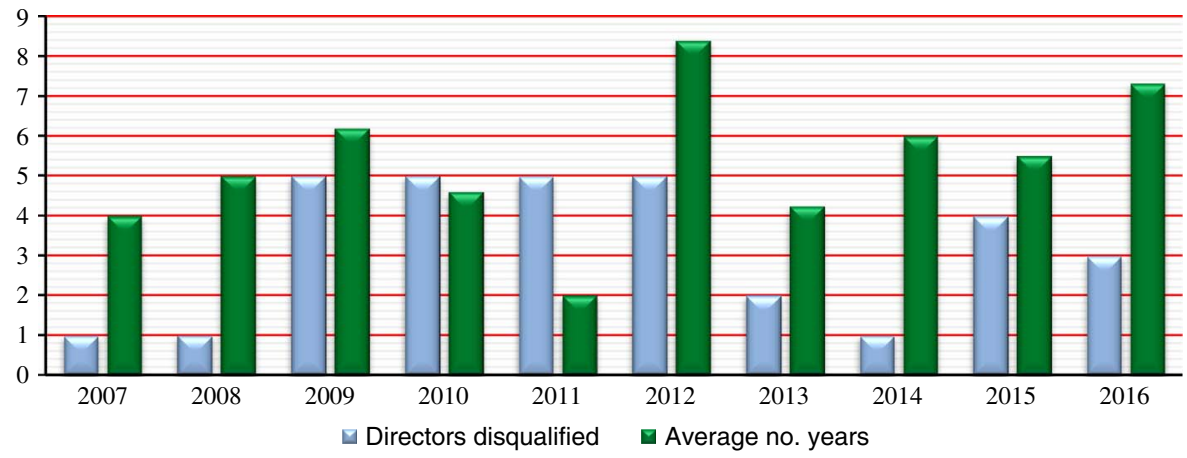

Figure 3. Directors disqualified by SFC actions

Minth Group Ltd, a listed company in the autoparts industry with business primarily in mainland China. The SFC action alleged that the named directors engaged in undisclosed related party transactions resulting in the tunnelling of funds out of the group through overpriced acquisitions made by a Minth subsidiary. ${ }^{194}$ The SFC now began to combine disqualification actions with substantial civil suits against the same directors for disgorgement of profits and compensation of damages, such as its HK\$420 million (US\$53.8 million) in compensation awarded against former directors of GOME Electrical Appliances Holding Ltd. ${ }^{195}$

The SFC was clearly encouraged in its enforcement activity by a 2013 victory in a landmark challenge to its direct recourse to the Court of First Instance (CFI) in civil matters. In the case, the SFC sought an injunction pursuant to SFO section 213 in the CFI against a hedge fund, Tiger Asia Management LLC, to block use of what it alleged were the proceeds of insider dealing. The CFI read the SFO as restricting the SFC for all civil matters to the Market Misconduct Tribunal (MMT), ${ }^{196}$ which is not formally a "court" within the Hong Kong judiciary. ${ }^{197}$ This stopped the injunctive action and was likely to stymie future SFC enforcement activity. The SFC appealed, and both the Court of Appeal ${ }^{198}$ and the Court of Final Appeal ${ }^{199}$ held on the contrary that the SFC was not restricted to the MMT, but could seek relief immediately in the CFI under SFO section 213. It was shortly after this Court of Final Appeal decision that the Director of Public Prosecutions warned of excessive SFC power, as discussed above. As the Department of Justice's opinion of SFC power was probably known to the latter long before it was officially expressed, the Tiger Asia litigation was of great significance for the continuation of broad SFC enforcement efforts.

SFC-initiated actions are also beneficial for enriching Hong Kong case-law. The few derivative actions filed are inevitably settled after leave is granted. Although the SFC also has a formal procedure for settling petitions with a bargained period of disqualification, ${ }^{200}$ such actions are not usually settled with respect to all directors charged. Thus the

194. See SFC (2014c).

195. See SFC (2014b).

196. Securities and Futures Commission v. Tiger Asia Management LLC [2011] HKEC 824.

197. SFO, Part 13.

198. Securities and Futures Commission v. Tiger Asia Management LLC [2012] 2 HKLRD 281.

199. Securities and Futures Commission v. Tiger Asia Management LLC [2013] HKEC 703.

200. This is referred to as the Carecraft procedure, with reference to Re Carecraft Construction Co. Ltd [1994] 1 WLR 172. 


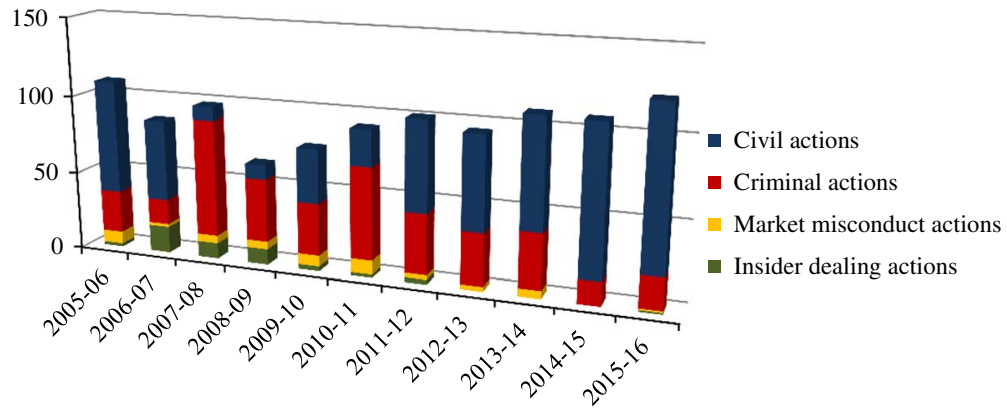

Figure 4. Total SFC actions

SFC-initiated actions provide the primary source of judicial decisions on the merits regarding directors' duties. This source of case-law is especially useful because the facts of the Hong Kong cases-in which complex multinational groups with a controlling shareholder find creative ways to tunnel funds to shareholder-directors ${ }^{201}$ —often differ from cases decided in the UK and the Commonwealth on similarly formulated duties.

\subsubsection{Actions against Market Misconduct}

In addition to policing licensed broker-dealers and investment advisers for compliance with licensing requirements, ${ }^{202}$ the SFC is also the primary enforcer of rules against market misconduct, primarily insider dealing and various forms of market manipulation. Figure 4 presents these enforcement actions in four categories of activity: persons charged in either a civil or criminal action, and persons charged with either insider dealing or market manipulation. The aggregate figures for civil and criminal actions greatly exceed the sum of insider dealing and market manipulation actions because these are only two of about 20 different types of charges arising in SFC enforcement activity, many of which regard behaviour of broker-dealers vis-à-vis clients and their funds. ${ }^{203}$

Beginning in 2006, the SFC began a "pragmatic shift in ... enforcement activities ... to send a potent message when breaches occur ... to take action which drives changes in behavior." 204 This meant that raw numbers of enforcement actions decreased while the number of high-profile, labour-intensive cases increased. ${ }^{205}$ For example, in 2008, the SFC exercised a hitherto dormant power provided under SFO section $385^{206}$ to intervene in a scheme of arrangement hearing through which PCCW Ltd (a company dominated by Richard Li, son of Hong Kong's wealthiest man,

201. See e.g. Re Styland Holdings Ltd (No. 2) [2012] 2 HKLRD 325.

202. SFC enforcement activities in this regard are discussed in Donald, supra note 8, pp. 211-13.

203. Aggregate data on these actions assembled from the SFC Enforcement News for the period between 1997 and 2013 are assembled in ibid., pp. 211-18.

204. SFC (2008), p. 6.

205. This trend of focusing on high-profile cases has continued into 2016. SFC's enforcement unit was reported to focus on "high-impact cases," especially using new technology to enable faster investigation; see Gismatullin \& Pham (2016). In SFC, "Enforcement Reporter" (No. 1 December, SFC 2016), it is explained that, after a comprehensive strategic review of enforcement priorities and organization structure, the SFC will focus its resources on high-priority cases and it formed a specialty team to focus on listed companies-related fraud and misfeasance.

206. SFO s. 385(1) provides that "[w]here there are any judicial or other proceedings (other than criminal proceedings) which concern a matter ... in which the Commission has an interest by virtue of its functions ... the Commission ... apply to intervene and be heard in the proceedings." 
Li Ka-shing) sought to squeeze out its public shareholders at an historically low price and delist voluntarily from the SEHK. ${ }^{207}$ Although a scheme designed by $\mathrm{Li}$ and his allies to manipulate voting rights was approved at the CFI, the SFC took it to the Court of Appeals, where it was held unfair, which rendered approval for the roll-up transaction invalid. ${ }^{208}$ In 2011, the SFC charged a Cayman Island company listed on the SEHK, Hontex International, with publishing misleading statements regarding its accounts in a securities prospectus. The SFC used SFO section 213 to obtain an order that Hontex must make a repurchase offer to all damaged shareholders ${ }^{209}$ at a value of HK\$1.03 billion. ${ }^{210}$ The SFC also revoked the licence of Hontex's lead manager (sponsor) for the listing, Mega Capital (Asia), levied a HK\$62 million (US\$8 million) fine ${ }^{211}$ and proceeded to issue new rules that would expressly subject such sponsors to a regime of duties and prospectus liability. Under this enforcement policy, actions for insider dealing have also been brought against persons connected with Citic Pacific Ltd $^{212}$ and ABN Amro Asset Management (Asia) Ltd. ${ }^{213}$ In 2012, the Court of Appeal upheld conviction of an officer of Morgan Stanley Asia Ltd in a case for insider dealing, although the defendant managed to get a reduced prison sentence of six years. ${ }^{214}$ The fine was also reduced from HK\$23.3 million in appeal to around HK\$1.7 million, but only in order to compensate for losses sustained by investors; in subsequent proceedings, the SFC obtained restoration orders requiring the former managing director to compensate a total of over HK\$23.9 million (US\$3 million) to 297 affected investors to restore their pre-transaction positions. ${ }^{215}$

\subsection{Companies Registry Actions}

The Companies Registry is by number of actions the most active supervisory body of corporate law in Hong Kong, but by purpose perhaps the most benign. Nearly all of the actions filed by the Companies Registry serve to chase outstanding filings, which the company could have omitted as a result of mere carelessness or which could also be a symptom of more serious offences being committed within the company. As discussed in Section 3, the Hong Kong Companies Ordinance contains a very large number of regular filings that all of the 1.3 million local and registered foreign companies with a place of business in Hong Kong must file regularly with the registry. These filings make Hong Kong one of the most transparent jurisdictions in the world, and range from statements of indebtedness and outstanding charges, to the structure of share capital, all the way up to reports prepared by directors presenting significant risks and challenges facing the business of the company. In most cases, failure to make a filing constitutes an offence, for which the offender may be brought into court and sanctioned. Sanctions include fines and the striking of the company out of the registry, but can also include under appropriate circumstances disqualification of company directors. Figure 5 presents the available public data on enforcement supplemented through correspondence with the Companies Registry. It includes total summons

207. SFC (2009).

208. Re PCCW Ltd [2009] HKEC 738 (CA).

209. SFC (2011). The power of the SFC to seek relief directly from the CFI was initially rejected, but then approved by the CA and the CFA. This is discussed in the next paragraph.

210. SFC (2012a).

211. SFC (2012b).

212. Securities and Futures Commission v. Chui Wing Nin [2013] HKEC 1483.

213. Leung Chi Keung v. Market Misconduct Tribunal [2012] HKEC 535.

214. See HKSAR v. Du Jun [2012] HKEC 1280; HKSAR v. Du Jun [2012] HKCA 391.

215. See SFC (2013a). 


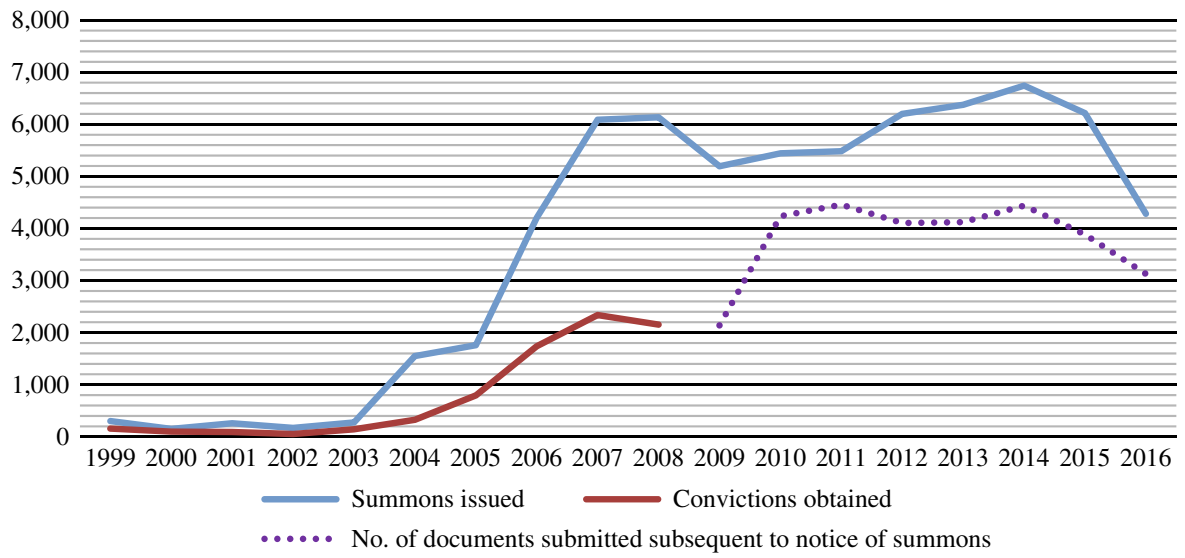

Figure 5. Actions by Companies Registry: summons, convictions, and compliance

issued, the success rate up until 2008, and thereafter from 2009 the rate of compliance after the issuing of a summons. Most of the registry's actions are for fines and other penalties, rather than for disqualification of directors. The graph shows rapidly increasing case numbers between 2000 to 2007 , followed by a downward trend since 2014. As per the Company Registry, this decrease in formal actions resulted from the availability of a power under the new Companies Ordinance $^{216}$ allowing the registry to forgo prosecution of a company in breach of the ordinance if it pays a required fee, thus settling the matter at the administrative level and reducing court costs. ${ }^{217}$ From 2014, the gap between number of summons and rate of compliance continues to narrow, which would be consistent with an increasing efficacy of enforcement.

\subsection{Official Receiver Actions}

When the OR assumes control of a company entering into winding-up, it obtains very good information on the state of the company and a substantial amount of information on the behaviour of the management in the lead-up to the company's collapse. The CWUMPO gives the receiver power to seek the disqualification of a director if it "is in the public interest that a disqualification order" be made. ${ }^{218}$ The receiver can also seek action against a director for "fraudulent trading" that drives the company into insolvency, which can result in the director becoming liable for the company's debts, committing a criminal offence, and being disqualified from management office for the longest period permitted under the statute. ${ }^{219}$ Figure 6 sets out the record of the OR on disqualification orders sought and obtained during the most recent period of ten years, including 2016.

216. CAP 622, which entered into effect from March 2014, creates in its Part 2, Division 5, a broad but limited set of powers in the Companies Registry with regard to maintaining the Companies Register, including direct amendment of filed documents, demand that a filing company rectify, imposition of fees, and prosecution of offences specified in the ordinance.

217. Another factor for the downward trend, in line with the theme of enhancing enforcement efficiency, is that the Companies Registry takes striking off action against non-complying and defunct companies, instead of commencing prosecution action, thereby reducing the number of summons needed. In the period 2015-16, 73,638 companies were struck off as a result, compared to an annual average of around 24,000 in the previous five years.

218. CWUMPO s. $168 \mathrm{I}(1)$.

219. CWUMPO s. $168 \mathrm{~J}$. 


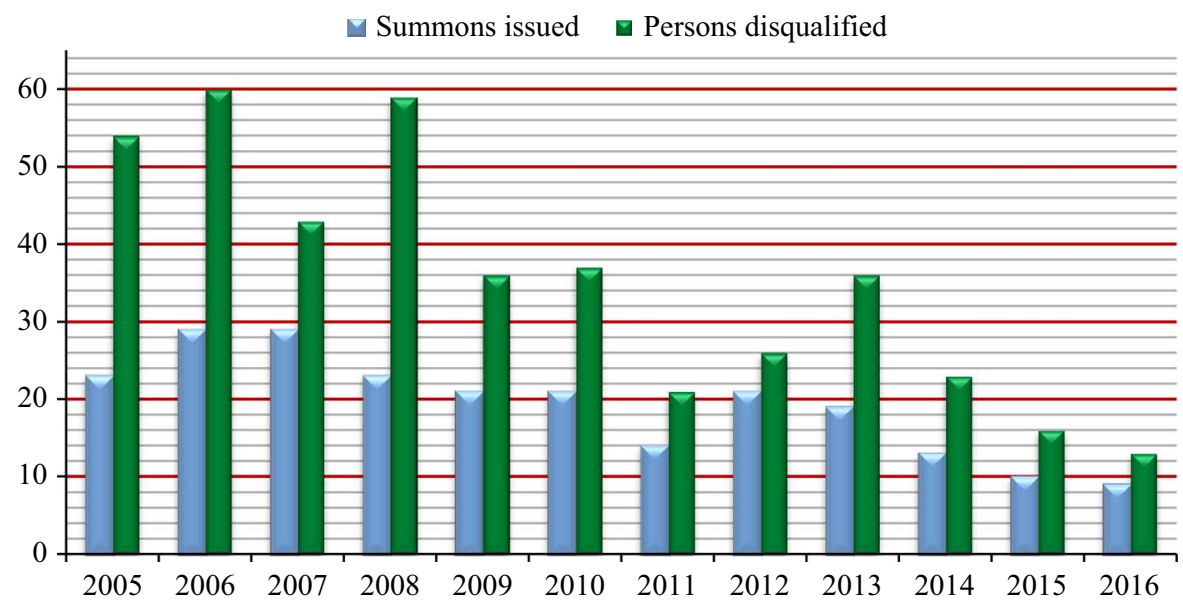

Figure 6. Official Receiver: summons and disqualifications

In the actions plotted above, the average period of disqualification obtained in each year ranges from 2.57 years to 4.11 years and, for the entire the period, disqualification averages about 3.3 years. The impact of such disqualification actions could be understood as essentially similar to rules in some civil-law countries against the directors of an insolvent company resuming the position of director, ${ }^{220}$ albeit probably less harsh, given the high bar for the disqualification application and the significant discretion of the court in crafting the order. Nevertheless, these orders serve not only to protect future investors, but also to deter the misconduct of existing directors, and are thus very useful for investor protection purposes. Barma J. (as he then was) explains the policy behind disqualification:

[T] he court will bear in mind first, the need to protect the public against the future conduct of persons who have shown themselves to be a danger to those dealing with the companies of which they are directors; and second, the need to provide a general deterrent by ensuring that the sentence reflects the gravity of the conduct complained of, thus sending a message to company directors that breaches of trust will be properly punished. ${ }^{221}$

Disqualification by the OR or the SFC presents a real deterrent for serious misconduct-one that cannot be insured against-while sanctions sought by the Companies Registry provide a deterrent against failure to provide regular information to the public. To these bodies, the HKEx can be seen as providing similar reinforcement of the many governance and disclosure standards expressed in its Listing Rules.

\subsection{HKEx Actions}

The HKEx has at its disposal a limited number of enforcement powers, ranging from a private reprimand to a public one, to the cancellation of an issuer's listing. Essentially, it can make public that a listed company has failed to meet its standards, and let the market inflict

220. See e.g. s. 76(3)(3)(b) of the German Stock Corporation Act, which flatly prohibits directors who have been found to behave culpably in connection with a former company's insolvency from serving as management board members for a period of five years.

221. Medical China Ltd [2012] HKEC 1407, para. 4. 


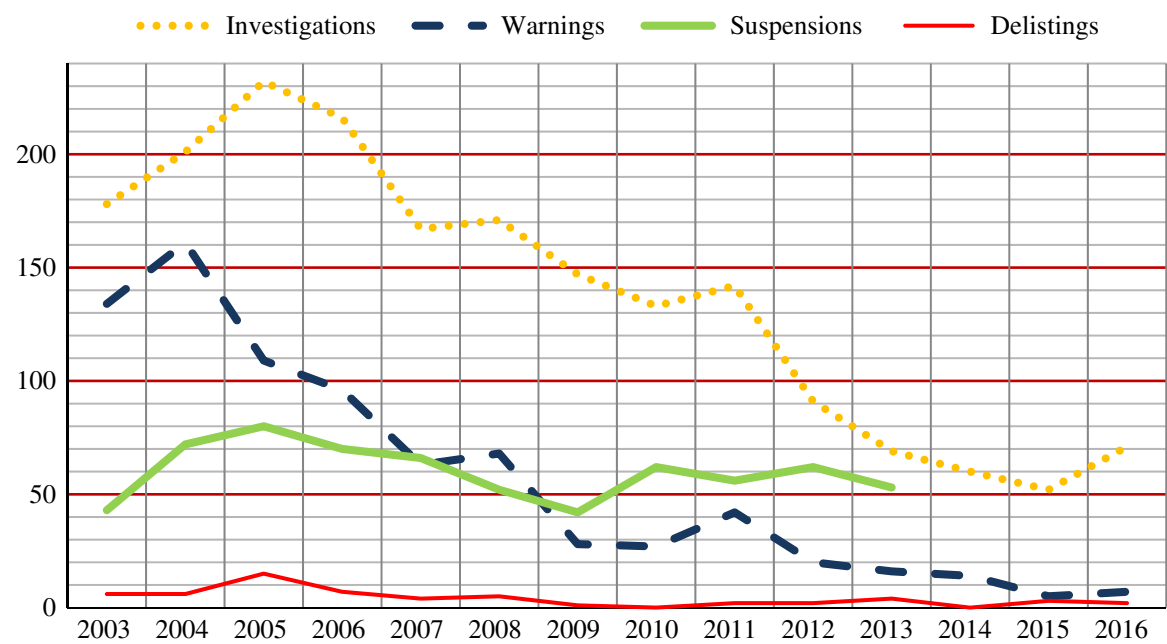

Figure 7. HKEx disciplinary actions against listed companies

punishment on the company's cost of capital or deny the same issuer access to its stock market. Figure 7 uses data drawn from HKEx annual reports and enforcement reports to show investigations, censures, suspensions, and delistings for the period from 2003 to 2015. The number of delistings is interpreted in the strictest possible sense, meaning only those issuers that were forcefully removed from the exchange during the year, and excluding those which received a warning of delisting and those that voluntarily delisted. The latter companies could have made such decision as a form of settlement with the exchange, and they have been included in the figures for delisting elsewhere. ${ }^{222}$

The rise and fall of investigations and suspensions between 2003 and 2007 parallel a similar trend in total SFC enforcement actions. As discussed above, the SFC made a deliberate choice to reduce the number of enforcement actions in favour of selected, high-impact enforcement. This could have set the tone for the HKEx. A spike of enforcement actions might well have been expected in the mid-2000s because this was a time of rapid growth for the SEHK. The absolute number of SEHK Main Board listings increased about 67\% between 2004 and 2007, from 49 to $82 .{ }^{223}$ The significant difference for the entire period between the number of investigations and delistings reflects the HKEx attempt to rehabilitate and reinstate companies that it had warned or even suspended. This is a classic conflict of interests for a securities exchange, and the HKEx is not free of it. The low rate of delistings could well indicate a tendency of the HKEx to keep as many issuers as possible listed on the SEHK, so as to build large market capitalization, but the lack of subsequent scandals affecting such companies may indicate that this practice has not been dangerous for investors.

Given the unique position of the HKEx in China, moreover, pandering to market capitalization size seems unlikely. The main commodity-aside from a freely convertible currency-that the HKEx sells to mainland Chinese companies seeking a (semi-)offshore listing is good governance. Thus, in trying to attract these companies to the SEHK, the HKEx has been in the

222. Donald, supra note 8, p. 221.

223. HKEx (2008). 
comfortable position of pleasing its customer the more vigorously it regulates them. If it were to lose its reputation for rigorous supervision, the HKEx would deflate one of the principal reasons that a Chinese company seeks a listing in Hong Kong. The importance to the HKEx of strong governance was evidenced in its rejection of Alibaba's request to allow the listing of two classes of shares with unequal voting rights. This conflicted with the SEHK Listing Rules and with a policy of equal voting that have allowed the SEHK to establish a market dominated by both family concerns and state-owned enterprises of the People's Republic of China (PRC), all of which have retained complete control of their companies while receiving funds from their IPOs. Relinquishing the hitherto largest IPO in history to New York provided solid evidence that the HKEx and the SFC take governance seriously.

\subsection{Direct Democratic Action: Hong Kong's Fifth Wheel}

In the context of studying Hong Kong's public enforcement model, it is worth examining a tool that has occasionally been used in Hong Kong, but is not provided for in any law or Constitution. It might be thought of as an appeal to quasi-customary principles. On occasion, when a part of the Hong Kong population sees itself as treated unjustly, it goes to the streets and in many cases the government responds by providing remedy. ${ }^{224}$ It is unclear whether the existence of this mechanism is a result of the small size of Hong Kong, where everyone is no more than an hour's commute from the seat of government, or from the fact that the government has lacked full democratic legitimacy, or from some other cause. Regardless of the reason, on a number of occasions, public protest has prompted the government into action. This "direct democratic action" was used during the global financial crisis to override the existing contract and securities law, and compensated many Hong Kong investors.

Between 2003 and 2008, about HK\$21 billion of Lehman Brothers arranged credit-linked notes locally called "minibonds" were sold to some 34,000 retail investors in Hong Kong. ${ }^{225}$ The securities prospectus used for most of these sales stated clearly that the notes were not guaranteed as to principal, and investors received credit support only through a swap agreement with a Lehman entity. Nevertheless, they were marketed and sold in Hong Kong to retail investors who needed safe assets to create a steady stream of retirement income. When Lehman entered insolvency proceedings, it was reasonable to assume that most of the HK $\$ 21$ billion investment would be lost. ${ }^{226}$ The damaged investors took to the streets and to the Legislative Council, arguing that, although the sale of the instruments might have been technically legal, what had happened was unfair.

In response, the Hong Kong government convinced the SFC and the Hong Kong Monetary Authority (HKMA) to negotiate a settlement with the distributing banks in Hong Kong for repurchase agreements. ${ }^{227}$ As a result, most of these investors received nearly $100 \%$

224. This was done, for example, to prevent Hong Kong's first chief executive from seeking a second term of office and to stop provisions of the new Companies Ordinance enacted in 2012 from carrying into force provisions offering privacy protection to directors' residential addresses and identification. See Donald, supra note 8, pp. 41-4.

225. HKMA (2011), p. 11.

226. SFC, supra note 207.

227. A total of 16 distributing banks participated in a settlement in which they repurchased notes from investors. These were the Bank of China (Hong Kong), the Bank of Communications, The Bank of East Asia, Chiyu Banking Corporation, Chong Hing Bank, CITIC Ka Wah Bank, Dah Sing Bank, Fubon Bank (Hong Kong), Industrial and Commercial Bank of China (Asia), MEVAS Bank, Nanyang Commercial Bank, Public Bank (Hong Kong), The Royal Bank of Scotland, Shanghai Commercial Bank, Wing Hang Bank, and Wing Lung Bank. See Hkma.gov.hk (2009). 
repayment on their investment, and another group received about $70 \%$ repayment (the difference being attributable to levels of collateralization on different tranches of notes). ${ }^{228}$ The settlement was achieved without any public enforcement action or private class action lawsuit, through negotiated settlement between the public authorities and the distributing banks, as might be done with a natural disaster relief fund (or, indeed, a bailout). Like a probable bailout for systemically important institutions, the possibility of such a "reverse bailout" (protecting taxpayers at the expense of the institutions rather than institutions at the expense of taxpayers) can be factored in when evaluating investor risk in Hong Kong.

\section{CONCLUSIONS}

The data on judicial actions taken pursuant to corporate and securities laws clearly show that such enforcement in Hong Kong is primarily public. This sharply contrasts to jurisdictions like the US, where private actions play a leading role, and contradicts much of the (older) scholarship on what works in corporate and securities regulation. The dominance of public enforcement in Hong Kong does not appear to be the result of statutory or judicial requirements for derivative or unfair prejudice actions being unusually restrictive. In fact, not only do the statutory rules compare well internationally, but Hong Kong courts have expressed a desire to accommodate and support shareholder protection. These courts have even broken with the general doctrine in UK and Commonwealth decisions to affirm an unfair prejudice action in the context of a listed company. However, the structure of lawyers' fees and types of actions in Hong Kong do not facilitate this form of private enforcement in the way that exists in the US legal system.

If private actions were taken as the touchstone of quality, as much of the (older) scholarship argues they should be, then this difference in litigation between the US and Hong Kong would indicate that Hong Kong investor protection is inadequate and unsuited to financial market growth. Facts clearly indicate otherwise. Hong Kong consistently ranks as the world's leading jurisdiction for IPO volume. Moreover-unlike the US, where all foreign contact is sanitized through use of American Depositary Receipts so that, on US markets, US-law securities trade exclusively in US dollars-Hong Kong must deal with an extremely unruly market in which it has no control over the corporate law of its issuers whose securities trade in every imaginable currency. Such listing volume in a very dangerous environment combined with a lack of instances in which fraud (on the scale of an Enron or Bernard Madoff) has been successful or public regulators have been entangled in scandal indicates that public enforcement is successful in Hong Kong. The data indicate that the various bodies prosecuting enforcement in Hong Kong are all well funded, and have generated a healthy output following rational enforcement policies.

Apparently, as Jackson, Roe, and Coffee all argue, public enforcement is indeed effective for financial market development, even in a jurisdiction regulating mostly foreign companies from jurisdictions with substandard systems of governance. Moreover, as Coffee has argued, enforcement mechanisms should not be designed to punish the victims. ${ }^{229}$ If, under the US model, shareholders ultimately pay for large civil judgments against the companies of

229. Coffee, supra note 3, p. 255. 
offending directors, victims are further burdened while wrongdoers go free, absent some reputational damage. The primary by-products are a transfer of wealth to the legal profession and a general deterrent effect given the transaction costs and reputational impact of such litigation. This is not an efficient arrangement, and Hong Kong indicates that it need not be emulated. The penalties imposed through public enforcement actions in Hong Kong-fines, disgorgement, and disqualification-may well have more impact on directors than do civil damages, as they cannot all be covered with D\&O insurance.

Were studies of the type undertaken in this paper to be replicated in enough jurisdictions globally, the missing data that kept Jackson and Roe from incorporating "outputs" into a quantified opinion on the relationship between public enforcement and financial market development would be available. A solid recommendation on successful corporate and securities enforcement mechanisms would be very useful for the policy formulation of developing countries and IFCs. Any such recommendations should go beyond exporting a leading model, and seek their basis in full data incorporating the entire context of the enforcement process.

\section{REFERENCES}

Armour, John, Bernard S. Black, \& Brian R. Cheffins (2012a) "Delaware's Balancing Act." 87 Indiana Law Journal 1345-405.

Armour, John, Bernard S. Black, \& Brian R. Cheffins (2012b) "Is Delaware Losing Its Cases?" 9 Journal of Empirical Legal Studies 605-56.

Armour, John, Bernard S. Black, Brian R. Cheffins, \& Richard Nolan (2009) "Private Enforcement of Corporate Law: An Empirical Comparison of the United Kingdom and the United States." 6 Journal of Empirical Legal Studies 687-722.

Arner, Douglas W. (2016) "Hong Kong: Evolution and Future as a Leading International Financial Centre," in J. Hu, M. Vanhullebusch \& A. Harding, eds., Finance, Rule of Law and Development in Asia, Boston: Brill, 49-75.

Bai, Lynn, James D. Cox, \& Randall S. Thomas (2010) "Lying and Getting Caught: An Empirical Study of the Effect of Securities Class Action Settlements on Targeted Firms." 158 University of Pennsylvania Law Review 1877-914.

Berkowitz, Daniel, Katharina Pistor, \& Jean-Francois Richard (2003) "The Transplant Effect." 51 American Journal of Comparative Law 163-203.

Bullock, Nicole (2014) “Alibaba Closes at \$93.89 in NYSE Debut.” The Financial Times, 20 September.

Carvajal, Ana, \& Jennifer A. Elliott (2009) "The Challenge of Enforcement in Securities Markets: Mission Impossible?" No. 9-168, IMF Working Paper 33, https://www.imf.org/external/pubs/ft/ wp/2009/wp09168.pdf (accessed 23 June 2017).

Cheffins, Brian, John Armour, \& Bernard Black (2012) "Delaware Corporate Litigation and the Fragmentation of the Plaintiff's Bar." 2012 Columbia Business Law Review 427-501.

Coates, John C., IV (2014) "Cost-Benefit Analysis of Financial Regulation: Case Studies and Implications." Harvard Law and Economics Discussion Paper No. 757.

Coffee, John C., Jr (2006) "Reforming the Securities Class Action: An Essay on Deterrence and Its Implementation." 106 Columbia Law Review 1534-86.

Coffee, John C., Jr (2007) "Law and the Market: The Impact of Enforcement." 156 University of Pennsylvania Law Review 229-311.

Cox, James D., \& Randall S. Thomas (2002) "Leaving Money on the Table: Do Institutional Investors Fail to File Claims in Securities Class Actions." 80 Washington University Law Review 855-81.

Cox, James D., \& Randall S. Thomas (2003) "SEC Enforcement Heuristics: An Empirical Inquiry." 53 Duke Law Journal 737-79. 
Cox, James D., \& Randall S. Thomas (2005a) "Letting Billions Slip Through Your Fingers: Empirical Evidence and Legal Implications of the Failure of Financial Institutions to Participate in Securities Class Action Settlements." 58 Stanford Law Review 411-54.

Cox, James D., \& Randall S. Thomas (2005b) "Public and Private Enforcement of the Securities Laws: Have Things Changed Since Enron?" 80 Notre Dame Law Review 893-907.

Cox, James D., \& Randall S. Thomas (2006) "Does the Plaintiff Matter? An Empirical Analysis of Lead Plaintiffs in Securities Class Actions." 100 Columbia Law Review 101-55.

Cox, James D., \& Randall S. Thomas (2009) "Mapping the American Shareholder Litigation Experience: A Survey of Empirical Studies of the Enforcement of the US Securities Law." 6.2-3 European Company and Financial Law Review 164-203.

Cox, James D., Randall S. Thomas, \& Lin Bai (2008) "There Are Plaintiffs and ... There Are Plaintiffs: An Empirical Analysis of Securities Class Action Settlements." 61 Vanderbilt Law Review 335-86.

Cumming, Douglas, April Knill, \& Nela Richardson (2015) "Firm Size and the Impact of Securities Regulation." 43 Journal of Comparative Economics 417-22.

Dam, Kenneth W. (2006) The Law-Growth Nexus: The Rule of Law and Economic Development, Washington DC: Brookings Institution Press.

Deakin, Simon (2010) "What Directors Do (and Fail To Do): Some Comparative Notes on Board Structure And Corporate Governance." 55 New York Law School Law Review $525-41$.

Department of Justice (2013) "Yearly Review of the Prosecutions Division 2012," http://www.doj.gov. hk/eng/public/pdf/pd2012/doj2012pd_full.pdf (accessed 5 June 2017).

Department of Justice (2017) "Legislative Council Panel on Administration of Justice and Legal Services-2017 Policy Initiatives of the Department of Justice," http://www.doj.gov.hk/eng/public/ pdf/2017/ajls0123e1.pdf (accessed 5 June 2017).

Department of Justice \& Securities and Futures Commission (2016) "Memorandum of Understanding between The Department of Justice of the Hong Kong Special Administrative Region and the Securities and Futures Commission," http://www.doj.gov.hk/eng/public/pdf/2016/memorandum_ e.pdf (accessed 5 June 2017).

Donald, David C. (2012) The Hong Kong Securities and Futures Exchanges-Law and Microstructure, Hong Kong: Sweet \& Maxwell.

Donald, David C. (2013) "Countering Corrupting Conflicts of Interest: The Example of Hong Kong," in J. Horder \& P. Alldridge, eds., Modern Bribery Law: Comparative Perspectives, Cambridge: Cambridge University Press, 66-94.

Donald, David C. (2014) A Financial Centre for Two Empires: Hong Kong's Corporate, Securities and Tax Laws in its Transition from Britain to China, Hong Kong: Cambridge University Press.

Echeverri-Gent, John, \& Benjamin Bloom (2010) "Does Competitive Politics Produce Competitive Markets? Politics of Financial Market Development," https://ssrn.com/abstract=1644631 (accessed 5 June 2017).

Eisenberg, Theodore, \& Geoffrey Miller (2004) "Attorney Fees in Class Action Settlements: An Empirical Study." 1 Journal of Empirical Legal Studies 27-78.

Eisenberg, Theodore, \& Geoffrey Miller (2006) "Incentive Awards to Class Action Plaintiffs: An Empirical Study." 53 UCLA Law Review 1303-51.

Eisenberg, Theodore, \& Geoffrey Miller (2012) "English Versus the American Rule on Attorney Fees: An Empirical Study of Public Company Contracts." 98 Cornell Law Review 327-82.

Fell, Robert (1992) Crisis and Change: The Maturing of Hong Kong's Financial Markets, 1981-1989, Hong Kong: Longman.

Ferran, Ellis, Niamh Moloney, Jennifer G. Hill, \& John C. Coffee, Jr (2012) The Regulatory Aftermath of the Global Financial Crisis, Cambridge: Cambridge University Press.

Frankel, Jeffrey A., Nancy Birdsall, Jeffrey Sachs, \& Guillermo Ortiz (2003) "Panel Discussion: Promoting Better National Institutions: The Role of the IMF." 50 IMF Staff Papers 21-41.

Gismatullin, Eduard, \& Lisa Pham (2016) "Hong Kong Financial Regulator Plans Specialist Probe teams," Bloomberg, 5 October. 
Griffith, John (2006) "Uncovering a Gatekeeper: Why the SEC Should Mandate Disclosure of Details Concerning Directors' and Officers' Liability Insurance Policies." 154 University of Pennsylvania Law Review 1147-208.

HKMA (2011) Annual Report 2010, Hong Kong: Hong Kong Monetary Authority.

Hkma.gov.hk (2009) "Questions and Answers About Lehman Brothers Minibonds Repurchase Scheme By Distributing Banks," http://www.hkma.gov.hk/eng/other-information/lehman/lehman_repurchase_ faq.shtml (accessed 5 June 2017).

HKSAR Gov (2017) "HKSAR Budgets, Head 116-The Official Receiver's Office," http://www. budget.gov.hk/2017/eng/pdf/head116.pdf (accessed 5 June 2017).

Hong Kong Census and Statistics Department (2015) Hong Kong Annual Digest of Statistics, Hong Kong: Hong Kong SAR Gov.

Hong Kong Exchanges and Clearing Limited (HKEx) (2000) "HKEx Fact Book-1999," https://www. hkex.com.hk/eng/stat/statrpt/factbook/fb1999.htm (accessed 5 June 2017).

Hong Kong Exchanges and Clearing Limited (HKEx) (2008) HKEx Annual Report-2007, Hong Kong: HKEx.

Hong Kong Exchanges and Clearing Limited (HKEx) (2017a) HKEx Annual Report-2016, Hong Kong: HKEx.

Hong Kong Exchanges and Clearing Limited (HKEx) (2017b) "HKEx Fact Book-2016," https://www. hkex.com.hk/eng/stat/statrpt/factbook/factbook2016/Documents/01.pdf (accessed 5 June 2017).

Hurtado, Patricia, \& Michael Keller (2016) "How the Feds Pulled Off the Biggest Insider-trading Investigation in U.S. History," Bloomberg, 1 June.

IMF.org (2014) "IOSCO Objectives and Principles of Securities Regulation-Detailed Assessment of Observance: Hong Kong Special Administrative Region, IMF Report No. 14/205," https://www. imf.org/external/pubs/ft/scr/2014/cr14205.pdf (accessed 5 June 2017).

Jackson, Howell E., \& Mark J. Roe (2009) "Public and Private Enforcement of Securities Laws: Resource-Based Evidence." 93 Journal of Financial Economics 207-38.

Jackson, Howell E., \& Jeffery Y. Zhang (2017) "Private and Public Enforcement of Securities Regulation," in J. Gordon \& W. Ringe, eds., Oxford Handbook of Corporate Law and Governance (forthcoming).

Jacques, Martin (2014) "China is Hong Kong's Future—Not Its Enemy," The Guardian, 30 September. Jennings, Jared N., Simi Kedia, \& Shivaram Rajgopal (2012) "The Deterrent Effects of SEC Enforcement and Class Action Litigation," https://ssrn.com/abstract=1868578 (accessed 5 June 2017).

Johnston, Rick, \& Reining Petacchi (2017) "Regulatory Oversight of Financial Reporting: Securities and Exchange Commission Comment Letters." Contemporary Accounting Research (forthcoming).

Katz, Stanley Nider (2009) Oxford International Encyclopedia of Legal History, Oxford: Oxford University Press.

Kraakman, Reinier, John Armour, Paul Davies, Luca Enriques, Henry Hansmann, Gerard Hertig, Klaus Hopt, Hideki Kanda, Mariana Pargendler, Wolf-Georg Ringe, \& Edward Rock (2009) The Anatomy of Corporate Law: A Comparative and Functional Approach, Oxford: Oxford University Press.

La Porta, Rafael, Florencio Lopez-De-Silanes, \& Andrei Shleifer (2006) "What Works in Securities Law." 61 The Journal of Finance 1-32.

La Porta, Rafael, Florencio Lopez-de-Silanes, Andrei Shleifer, \& Rober W. Vishny (1997) "Legal Determinants of External Finance." 52 The Journal of Finance 1131-50.

Langevoort, Donald C. (2009) "The SEC, Retail Investors and the Institutionalization of the Securities Market." 95 Vanderbilt Law Review 1025-83.

Law Reform Commission of Hong Kong (2012) Report on Class Actions, Hong Kong: Law Reform Commission.

Leavenworth, Stuart (2016) "Britain Accuses China of Serious Breach of Treaty Over 'Removed' Hong Kong Booksellers," The Guardian, 12 February.

Legislative Council Panel on Financial Affairs (2015) Securities and Futures Commission Budget for the Financial Year 2015-16, http://www.legco.gov.hk/yr14-15/english/panels/fa/papers/fa20150 202cb1-445-5-e.pdf (accessed 23 June 2017). 
Lohse, Tim, Razvan Pascalau, \& Christian Thomann (2014) "Public Enforcement of Securities Market Rules: Resource-Based Evidence from the Securities and Exchange Commission." 106 Journal of Economic Behavior \& Organization 197-212.

Longfinance.net (2017) "The Global Financial Centres Index," http://www.longfinance.net/ programmes/global-financial-centres-index.html (accessed 5 June 2017).

Meng, Fanpeng (Frank) (2011) "A History of Chinese Companies Listing in Hong Kong and Its Implications for the Future." 11 Journal of Corporate Law Studies 243-66.

Michaels, Ralf (2006) "The Functional Method of Comparative Law," in M. Reimann \& R. Zimmermann, eds., The Oxford Handbook of Comparative Law, Oxford: Oxford University Press, 339-82.

Milhaupt, Curtis J., \& Katharina Pistor (2008) Law and Capitalism: What Corporate Crises Reveal About Legal Systems and Economic Development Around the World, Chicago and London: The University of Chicago Press.

New York Times Editorial (2016) "China Bullies Hong Kong," The New York Times, 9 November.

O'Sullivan, Noel (1997) "Insuring the Agents: The Role of Directors' and Officers' Insurance in Corporate Governance." 64 Journal of Risk and Insurance 545-56.

Oro.gov.hk (2017) "Organization Chart: Legal Services Division 2," http://www.oro.gov.hk/eng/ aboutus/ochart_04.htm (accessed 5 June 2017).

Process Review Panel for the SFC (2012) "Annual Report of the Process Review Panel for the Securities and Futures Commission," http://www.fstb.gov.hk/fsb/topical/doc/prereport11_e.pdf (accessed 5 June 2017).

Sevastopulo, Demetri (2014) "UK Top Judge: HK Independence Not Eroded," Financial Times, 27 August.

SFC (1988) The Operation and Regulation of the Hong Kong Securities Industry, Hong Kong: Securities and Futures Commission.

SFC (2004) Annual Report 2003-2004, Hong Kong: Securities and Futures Commission.

SFC (2008) Annual Report 2007-2008, Hong Kong: Securities and Futures Commission.

SFC (2009) "Court Grants SFC Application to Intervene in PCCW Scheme of Arrangement," SFC Enforcement News, 12 December.

SFC (2011) "SFC Seeks Final Orders in Hontex Case," SFC Enforcement News, 19 May.

SFC (2012a) "Hontex Issues Repurchase Offer to Shareholders," SFC Enforcement News, 24 September.

SFC (2012b) "SFC Fines and Revokes the License of Mega Capital (Asia) Company Limited," SFC Enforcement News, 22 April.

SFC (2013a) "Court Orders Insider Dealer Du Jun to Pay \$23.9 Million to Investors," SFC Enforcement News, 12 December.

SFC (2013b) "SFC Statement on Prosecutorial Responsibility," 30 August, http://www.sfc.hk/ edistributionWeb/gateway/EN/news-and-announcements/news/corporate-news/doc?refNo=13PR86 (accessed 5 June 2017).

SFC (2014a) Annual Report 2013-14, Hong Kong: Securities and Futures Commission.

SFC (2014b) "SFC Obtains Court Orders for GOME to Receive \$420 Million Compensation from Founder and Wife over Breaches in Share Repurchase," SFC News Release, 7 May.

SFC (2014c) "SFC Seeks Court Orders against Chairman, Current and Former Directors of Minth Group Limited," SFC News Release, 15 April.

SFC (2015) Annual Report 2014-15, Hong Kong: Securities and Futures Commission.

SFC (2016) Annual Report 2015-16, Hong Kong: Securities and Futures Commission.

Siems, Mathias M. (2010) "Private Enforcement of Directors' Duties: Derivative Actions as a Global Phenomenon," in S. Wrbka, S. Van Uytsel \& M. Siems, eds., Collective Actions: Enhancing Access to Justice and Reconciling Multilayer Interests, Cambridge: Cambridge University Press, 93-116.

Velikonja, Urska (2015) "Public Compensation for Private Harm: Evidence From the SEC's Fair Fund Distributions." 67 Stanford Law Review 331-95. 
Vermeulen, Erik P. M., \& Dirk A. Zetzsche (2010) "The Use and Abuse of Investor Suits: An Inquiry Into the Dark Side of Shareholder Activism." 7 European Company and Financial Law Review 1-62.

Worldbank.org (2006) "Institutional Foundations for Financial Markets," http://siteresources. worldbank.org/INTTOPACCFINSER/Resources/Institutional.pdf (accessed 5 June 2017).

Worldjusticeproject.org (2016) "Rule of Law Index 2016," http://data.worldjusticeproject.org/ (accessed 5 June 2017).

Yu, Enoch (2013) "Minibond Saga Drawing to a Close," South China Morning Post, 4 June.

Zweigert, Konrad, \& Hein Kötz (1998) Introduction to Comparative Law, Oxford: Oxford University Press. 